\title{
U.S. Geological Survey Chesapeake Science Strategy, 2015-2025-Informing Ecosystem Management of America's Largest Estuary
}

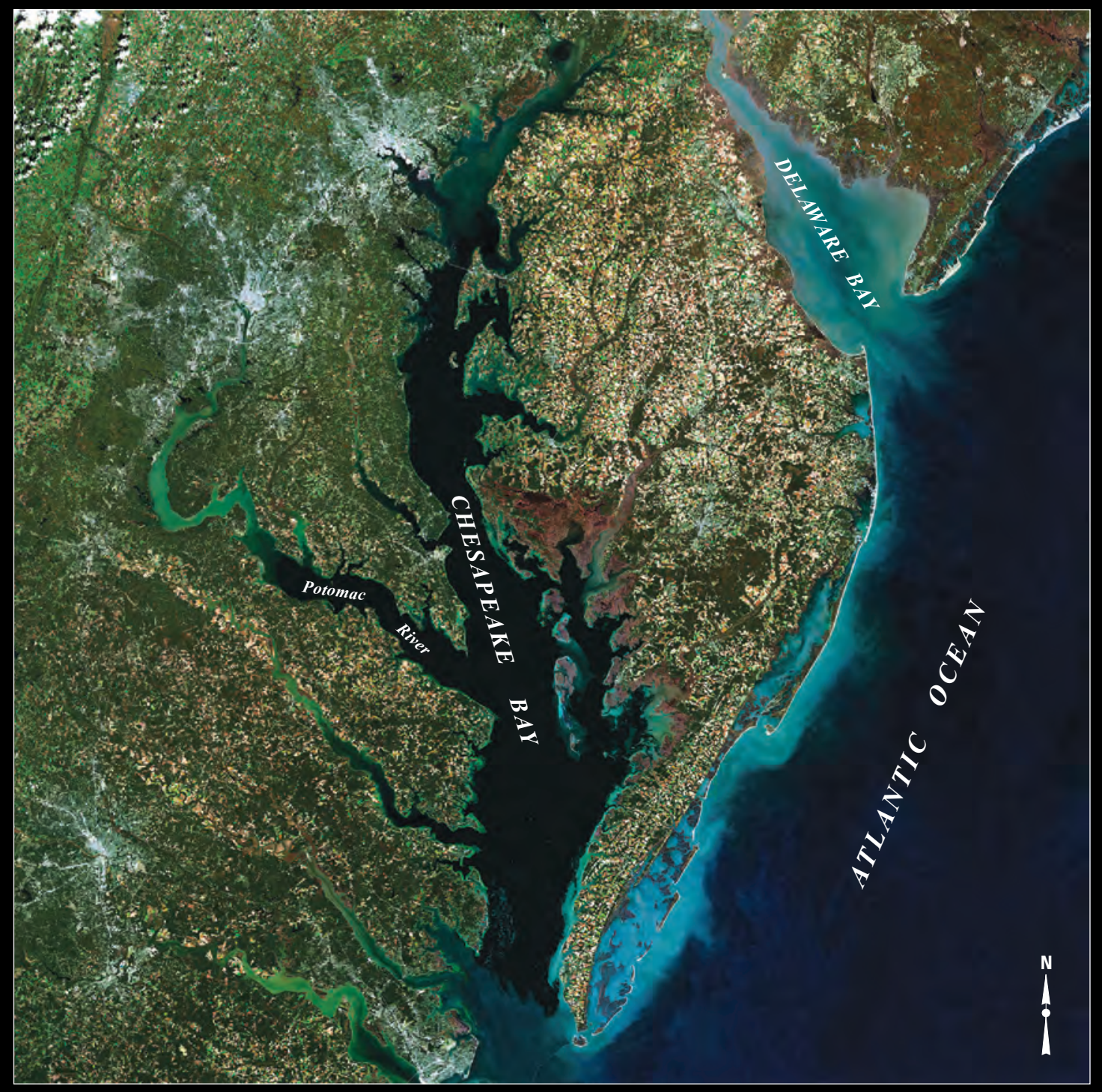

Open-File Report 2015-1162 
Cover. Landsat 8 Surface Reflectance Mosaic created at the USGS Earth Resources Observation and Science (EROS) Center using Provisional Surface Reflectance data from five Landsat 8 scenes acquired in October and November 2014 (http://landsat. usgs.gov/gallery_view_individual.php?pictureld=371). Landsat is jointly supported by NASA and USGS. 


\section{U.S. Geological Survey Chesapeake Science Strategy, 2015-2025-Informing Ecosystem Management of America's Largest Estuary}

Scott Phillips and Joel Blomquist, Editors

Chapters prepared by Mark Bennett, Alicia Berlin, Vicki Blazer, Joel Blomquist, Peter Claggett, Stephen Faulkner, Kenneth Hyer, Cassandra Ladino, Douglas Moyer, Rachael Muir, Gregory Noe, Patrick Phillips, and Scott Phillips

Open-File Report 2015-1162 


\title{
U.S. Department of the Interior SALLY JEWELL, Secretary
}

\section{U.S. Geological Survey Suzette M. Kimball, Acting Director}

\author{
U.S. Geological Survey, Reston, Virginia: 2015
}

For more information on the USGS - the Federal source for science about the Earth, its natural and living resources, natural hazards, and the environment, visit http://www.usgs.gov or call 1-888-ASK-USGS

For an overview of USGS information products, including maps, imagery, and publications, visit http://www.usgs.gov/pubprod

To order this and other USGS information products, visit http://store.usgs.gov

Any use of trade, product, or firm names is for descriptive purposes only and does not imply endorsement by the U.S. Government.

Although this report is in the public domain, permission must be secured from the individual copyright owners to reproduce any copyrighted materials contained within this report.

Suggested citation:

Phillips, Scott, and Blomquist, Joel, eds., 2015, U.S. Geological Survey Chesapeake science strategy, 2015-2025Informing ecosystem management of America's largest estuary: U.S. Geological Survey Open-File Report 2015-1162, 43 p., http://dx.doi.org/10.3133/ofr20151162.

ISSN 2331-1258 (online) 


\section{Contents}

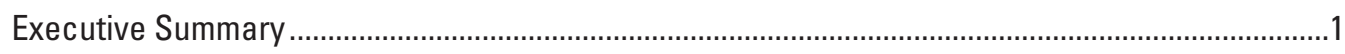

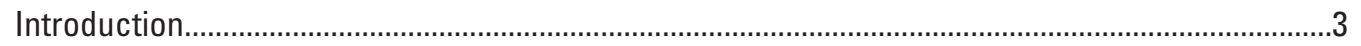

Chesapeake Bay—An Important but Degraded Ecosystem .....................................................

Chesapeake Restoration-President's Executive Order and Chesapeake

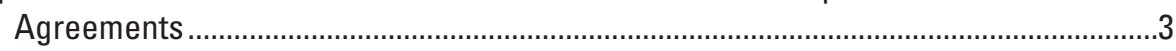

Role of the USGS

Overview of USGS Chesapeake Science Strategy, 2015-2025 ..................................................

New USGS Chesapeake Bay Science Themes and Objectives ……….....................................

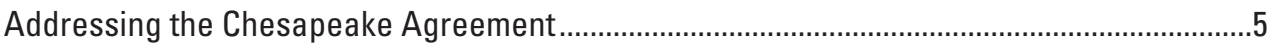

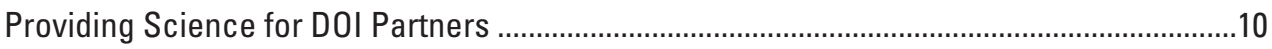

Collaborating with the USGS Mission Areas .......................................................................

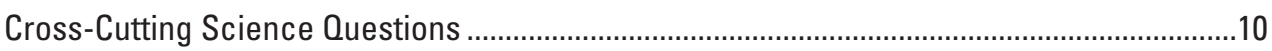

Science Theme 1: Enhance Science to Support Restoration and Conservation of Fish,

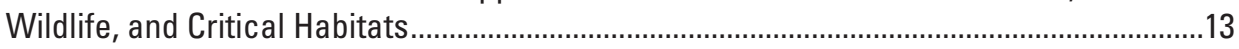

Objective 1.1 Enhance Science to Support Management of Freshwater Fish

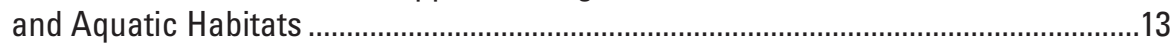

Objective 1.2 Characterize the Sources and Effects of Environmental Stresses and Toxic Chemicals on Fish and Wildlife..............................................................16

Objective 1.3 Improve Understanding of Coastal Ecosystem Structure, Function, and Resiliency to Manage Waterbirds .................................................................18

Science Theme 2: Characterize and Explain Changes in Water Quality and Its Effect

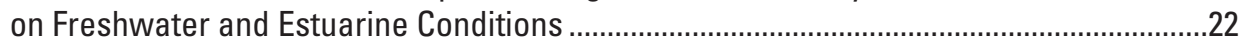

Objective 2.1 Characterize Status and Trends in Nutrients, Sediment, and

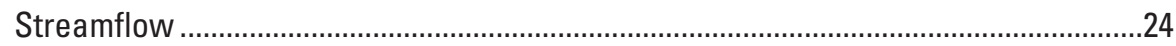

Objective 2.2 Explain Water-Quality Changes in Response to Human Actions........................25

Objective 2.3 Collaborate to Integrate Hydrology and Water Quality with Freshwater and Estuarine Ecosystem Assessments ...............................................28

Science Theme 3: Assess and Forecast Effects of Climate and Land Change on Ecosystem Conditions ......................................................................................................31

Objective 3.1 Assess the Combined Effects of Climate and Land Change on Streams and Fisheries ...........................................................................................

Objective 3.2 Assess the Effects of Sea-Level Rise and Land Development on Wetlands and Ecosystem Conditions and their Resiliency .....................................33

Objective 3.3 Characterize and Forecast Land Change and Provide Implications for Conservation .......................................................................................

Science Theme 4: Synthesize and Provide Information to Support Ecosystem

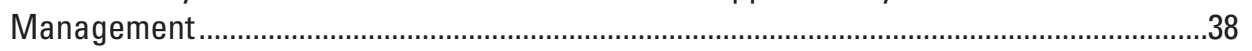

Objective 4.1 Summarize and Apply Science to Inform Decision Making …….......................38

Objective 4.2 Manage and Provide Information .....................................................................

Objective 4.3 Lead Collaborative Science Activities ..................................................................41

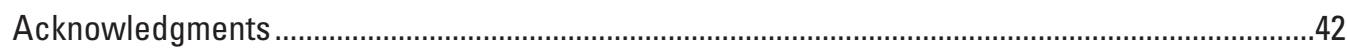

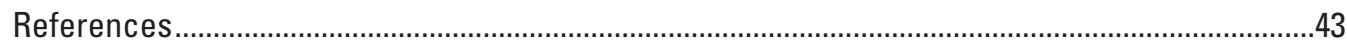

Appendix. Chesapeake Agreement...................................................................................... 


\section{Figures}

1. Map showing the location of Chesapeake Bay watershed ..............................................

2. Conceptual diagram of Chesapeake Bay ecosystem .........................................................

3. Diagram showing the relation between U.S. Geological Survey (USGS)

Mission Areas, Chesapeake Bay science themes, and decision-making entities

4. Map showing Brook Trout range and selected U.S. Geological Survey (USGS) study locations.

5. Map showing U.S. Geological Survey (USGS) fish health study locations.....................19

6. Map showing current U.S. Geological Survey (USGS) study sites for

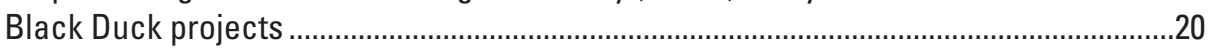

7. Map showing location of selected water-quality networks...........................................26

8. Map showing location of U.S. Geological Survey (USGS) groundwater modeling areas, long-term and short-term trend monitoring stations, regional synthesis areas, and small watershed study areas.

9. Map showing U.S. Geological Survey (USGS) streamflow-gaging network, nontidal network stations, and their intersection with Fisheries studies locations

10. Map showing U.S. Geological Survey (USGS) studies of sea-level rise and coastal change will focus both on the U.S. Fish \& Wildlife (FWS) sites (shown) and additional near-shore areas.

11. Map showing location of protected lands and healthy watersheds in the Chesapeake Bay ecosystem.

12. Diagram showing adaptive management framework for the Chesapeake Bay Program (CBP). 39

13. Diagram showing the relation between Chesapeake Bay Program (CBP) goals, decision makers, and U.S. Geological Survey (USGS) activities

\section{Tables}

1. Relation between Chesapeake Bay Executive Order Strategy, Chesapeake Bay Watershed Agreement Goals, and U.S. Geological Survey (USGS) Chesapeake Science Themes

2. Relation between U.S. Geological Survey (USGS) Chesapeake Science Themes, Objectives, Mission Areas, and Outcomes of Chesapeake Agreement

3. Chesapeake Agreement, 2014-2025-Goals, Outcomes, and Lead Federal Agencies

4. U.S. Geological Survey (USGS) Mission Areas and Associated Science Strategy Goals. 


\section{Conversion Factors}

\begin{tabular}{|c|c|c|}
\hline Multiply & By & To obtain \\
\hline \multicolumn{3}{|c|}{ Length } \\
\hline mile (mi) & 1.609 & kilometer $(\mathrm{km})$ \\
\hline \multicolumn{3}{|c|}{ Area } \\
\hline acre & 4,047 & square meter $\left(\mathrm{m}^{2}\right)$ \\
\hline acre & 0.4047 & hectare (ha) \\
\hline acre & 0.4047 & square hectometer $\left(\mathrm{hm}^{2}\right)$ \\
\hline acre & 0.004047 & square kilometer $\left(\mathrm{km}^{2}\right)$ \\
\hline square mile $\left(\mathrm{mi}^{2}\right)$ & 259.0 & hectare (ha) \\
\hline square mile $\left(\mathrm{mi}^{2}\right)$ & 2.590 & square kilometer $\left(\mathrm{km}^{2}\right)$ \\
\hline \multicolumn{3}{|c|}{ Mass } \\
\hline pound, avoirdupois (lb) & 0.4536 & kilogram $(\mathrm{kg})$ \\
\hline
\end{tabular}

Temperature in degrees Celsius $\left({ }^{\circ} \mathrm{C}\right)$ may be converted to degrees Fahrenheit $\left({ }^{\circ} \mathrm{F}\right)$ as follows:

$$
{ }^{\circ} \mathrm{F}=\left(1.8 \mathrm{x}^{\circ} \mathrm{C}\right)+32
$$

Temperature in degrees Fahrenheit $\left({ }^{\circ} \mathrm{F}\right)$ may be converted to degrees Celsius $\left({ }^{\circ} \mathrm{C}\right)$ as follows:

$$
{ }^{\circ} \mathrm{C}=\left({ }^{\circ} \mathrm{F}-32\right) / 1.8
$$





\title{
U.S. Geological Survey Chesapeake Science Strategy, 2015-2025 - Informing Ecosystem Management of America's Largest Estuary
}

\author{
Scott Phillips and Joel Blomquist, Editors
}

\begin{abstract}
Chapters prepared by Mark Bennett, Alicia Berlin, Vicki Blazer, Joel Blomquist, Peter Claggett, Stephen Faulkner, Kenneth Hyer, Cassandra Ladino, Douglas Moyer, Rachel Muir, Gregory Noe, Patrick Phillips, and Scott Phillips
\end{abstract}

\section{Executive Summary}

The U.S. Geological Survey (USGS) has the critical role of providing scientific information to improve the understanding and management of the Chesapeake Bay ecosystem. The USGS works with Federal, State, and academic science partners to provide research and monitoring, and communicate results of these activities to enhance ecosystem management for both the Chesapeake and other National ecosystems. The USGS Chesapeake Science Strategy was prepared to guide science activities to address the Chesapeake Bay Watershed Agreement (2014-2025), to support the Department of the Interior (DOI) involvement in the Bay restoration efforts, and align with the USGS Mission Area (MA) Science strategies.

The Chesapeake Bay is our Nation's largest estuary, and provides critical goods and services to the people, fish, and wildlife that use the 64,000-square-mile watershed. The Chesapeake Bay watershed contains over 3,600 species of fish, wildlife, and plants and provides spawning grounds for many ecologically and economically important species including striped bass and blue crabs. The Bay watershed lies in the heart of the Atlantic Flyway and has 29 species of waterfowl, about 1 million of which winter in the region. The size of the Chesapeake seafood harvest is third in the Nation, only behind the Atlantic and Pacific Oceans. Along with agricultural production, tourism, and recreation, the estimated economic value of the services from the Chesapeake Bay watershed is about $\$ 100$ billion annually. However, the health of the Bay ecosystem began to decline at the beginning of the 20th century due to overfishing and increasing human population and associated land change.
The Chesapeake Bay Program (CBP) is the Federal-State cooperative effort that started in 1983 to restore the Bay and watershed. Given the ecological and economic importance of the Chesapeake ecosystem, President Obama issued an Executive Order (EO) in 2009 for increased Federal leadership in the CBP to enhance the pace of restoration, and the supporting strategy was released in 2010. The EO directed the Federal Government, including the U.S. Department of the Interior (DOI), represented by the National Park Service (NPS), the U.S. Fish \& Wildlife Service (FWS), and the USGS, to expand its efforts and increase leadership to restore the Bay and its watershed. The USGS and other Federal agencies expanded their activities in 2011 to meet the President's Chesapeake EO. Since the EO was released, there have been several important changes in the USGS, DOI, and the CBP including: (1) the Chesapeake Bay Watershed Agreement, (2) increased DOI leadership in the CBP, and (3) the release of the USGS MA science strategies. The EO strategy served as a foundation for the Chesapeake Bay Watershed Agreement that was signed in 2014 by the CBP Partners, and has goals and outcomes to be met by 2025 (table 1).

The USGS developed the Chesapeake Science Strategy to guide our activities to address the Chesapeake Bay Watershed Agreement, DOI leadership in the CBP, and USGS MA strategies. Improving the understanding of fish and wildlife population and health, and the factors affecting their condition is the emphasis of the Strategy. The science focuses on documenting the critical ecosystem connections in the Chesapeake, and providing implications to enhance decision making for restoration and conservation activities. 
Table 1. Relation between Chesapeake Bay Executive Order Strategy, Chesapeake Bay Watershed Agreement Goals, and U.S. Geological Survey (USGS) Chesapeake Science Themes.

[Bold, focus of USGS efforts for Goals in Agreement]

\begin{tabular}{l|l|l}
\hline \multicolumn{1}{c|}{$\mathbf{2 0 1 0}$ Executive Order Strategy Topics } & \multicolumn{1}{c}{$\begin{array}{c}\text { Chesapeake Bay Watershed Agreement } \\
\text { Goals and Principles, 2014-2025 }\end{array}$} & \multicolumn{1}{c}{$\begin{array}{c}\text { U.S. Geological Survey Chesapeake } \\
\text { Science Themes, 2015-2025 }\end{array}$} \\
\hline Sustain Fish And Wildlife & Sustaining Fisheries & $\begin{array}{c}\text { Provide Science to Support Restoration and } \\
\text { Conservation of Fish, Wildlife, and Habitat }\end{array}$ \\
\hline Recover Habitats & Vital Habitats & $\begin{array}{c}\text { Characterize and Explain Water-Quality } \\
\text { Conditions and Change }\end{array}$ \\
\cline { 2 - 3 } Restore Clean Water & Toxic Contaminants & $\begin{array}{c}\text { Assess and Forecast Effects of Climate and } \\
\text { Land Change }\end{array}$ \\
\cline { 2 - 3 } Conserve Land and Increase Public Access & Healthy Watersheds & Land Conservation \\
\cline { 2 - 3 } & Public Access & Assess and Forecast Effects of Climate and \\
\hline Expand Citizen Stewardship & Stewardship & Land Change \\
\hline Respond to Climate Change & Environmental Literacy & Synthesize and Provide Information to Support \\
Ecosystem Management
\end{tabular}

The revised Strategy has four themes that address 7 of the 10 goals in the Chesapeake Bay Watershed Agreement (table 1):

- Enhance science to support restoration, and conservation of fish, wildlife, and critical habitats.

- Characterize and explain changes in water quality, and its effect on freshwater and estuarine ecosystems.

- Assess and forecast effects of climate and land change on ecosystem conditions.

- Synthesize and provide information to support ecosystem management.

The structure and function of biological communities of the Bay and its watershed are extremely complex and are affected by a variety of stressors and conditions. To better define the issues being addressed, the USGS has developed cross-cutting questions that define some of the most important scientific challenges where multiple disciplines and collaborators are needed to address an issue. The initial questions include:

- How do land and climate changes affect freshwater fish communities, health, and habitats?

- What are the relations among land use, water quality, contaminants, and the health of fish and wildlife?

- How are coastal wetlands and their carrying capacity for waterbirds affected by changing climate and land use?

- How is the water quality of rivers and estuaries responding to restoration actions, and changing land use?

- What are some of the best opportunities for management actions to benefit multiple restoration outcomes? 


\section{Introduction}

\section{Chesapeake Bay—An Important but Degraded Ecosystem}

The Chesapeake Bay is our Nation's largest estuary, and provides critical goods and services to the people, fish, and wildlife that use the 64,000 -square-mile watershed. Over 3,600 species of fish, wildlife, and plants spend all or part of their life cycle in the Bay watershed (U.S. Environmental Protection Agency, 2008). The Chesapeake Bay (hereafter known as the Bay) is the East Coast spawning grounds for many ecologically and economically important species including striped bass and blue crabs (fig. 1). The Atlantic Flyway migration route, home to 29 species of waterfowl, runs through the watershed, which provides winter habitat for 1 million birds. The Bay and its tidal tributaries have 11,684 miles of shoreline - more than the entire U.S. West Coast (U.S. Environmental Protection Agency, 2008). The coastline and more than 100,000 miles of streams enhance property values and provide recreational opportunities for its 17 million residents and additional visitors. The Bay produces about 500 million pounds of seafood per year. Along with agricultural production, tourism, and recreation, the estimated annual economic value of the goods and services from the Chesapeake ecosystem is $\$ 100$ billion (Chesapeake Bay Foundation, 2014).

There has been a decline of populations, and health, of fish and wildlife in the Bay and its watershed due to degrading ecosystem conditions (fig. 2). Fish kills occur annually in both the estuary and watershed streams. Eutrophication in the estuary, due to excess nutrients, results in mortality of both shellfish and finfish in tidal waters. Toxic contaminants, including endocrine-disrupting compounds (EDCs), have compromised the reproductive systems of fish and made them more susceptible to disease (U.S. Environmental Protection Agency and others, 2012). Symptoms of degraded fish health include compromised reproductive systems, intersex conditions, skin lesions, and tumors. Several waterfowl species have also exhibited compromised reproductive systems due to toxic contaminants. Invasive species are causing some wildlife species and habitats to decline. These degraded fish and wildlife populations, and supporting conditions, have decreased the benefits and services that the Bay ecosystem provides to the 17 million people who live and work in the watershed.

The major drivers of change on the Chesapeake Bay ecosystem are (1) human population growth, and (2) climate change and variability (fig. 2). The human population in the Bay watershed has doubled over the past four decades, which has resulted in dramatic landscape changes (Claggett, 2007) and increased consumption of natural resources. The landscape changes include urbanization, suburban sprawl, loss of agricultural and forested lands, changes in agricultural practices, and increased waste loads. Climate change, especially

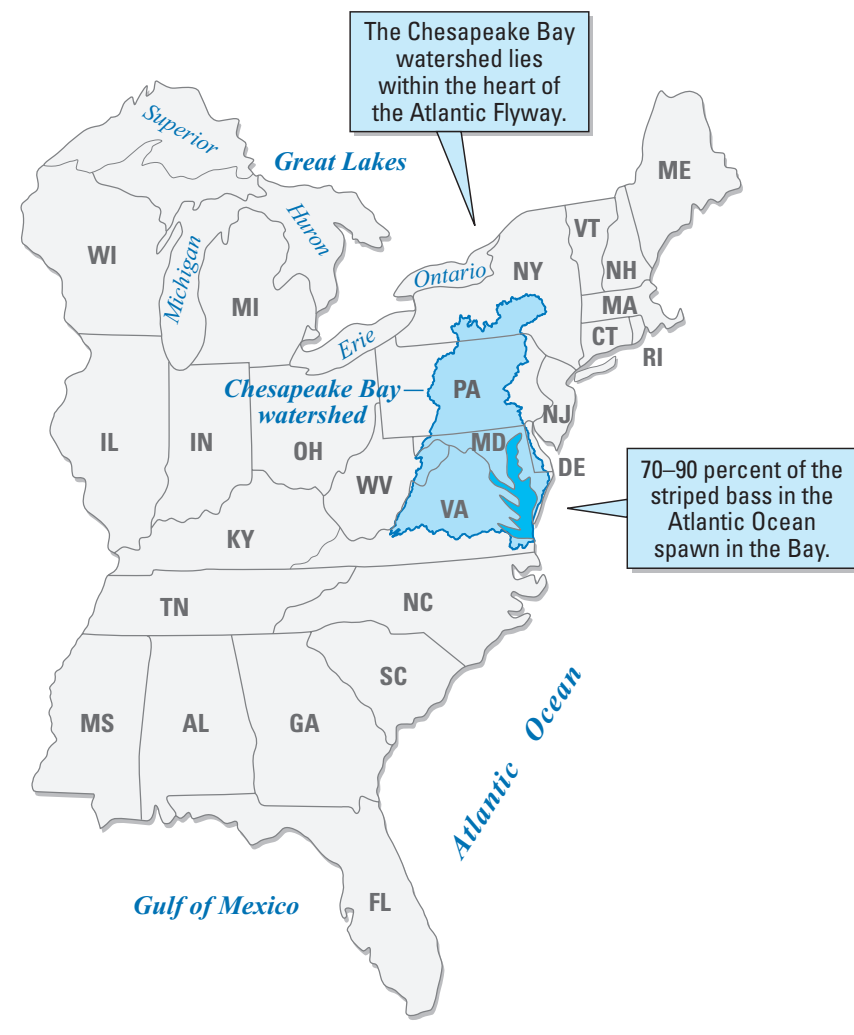

Figure 1. Location of Chesapeake Bay watershed. The Chesapeake Bay watershed is an important ecological landscape, which lies within the Atlantic Flyway, serves as a major spawning ground for fisheries on the East Coast, and provides ecological services estimated to be $\$ 100$ billion annually.

increased variability in precipitation events, causes changes to streamflow and their temperatures in the Bay watershed (Rice and Jastram, 2014). The landscape changes and climate variability have led to diminished watershed and estuary conditions, including poor water quality, degraded habitats, and loss of vital lands (Chesapeake Bay Program, 2013). There have been interventions, through management strategies and practices, to reduce the effects of stressors and thereby improve ecosystem conditions. The ecosystem conditions of the Chesapeake are similar to many other of the Nation's ecosystems, so what is learned in the Chesapeake can be transferred to other restoration efforts.

\section{Chesapeake Restoration-President's Executive Order and Chesapeake Agreements}

Restoration of the Chesapeake ecosystem began in 1983, led by the CBP. The CBP is a Federal-State partnership that includes the six states in the watershed, the District of Columbia, Federal agencies, local governments, and academic institutions. Partnership agreements have been signed in 1983, 1987, and 2000 with goals and commitments to restore the 


\section{CONCEPTUAL DIAGRAM OF CHESAPEAKE BAY ECOSYSTEM}

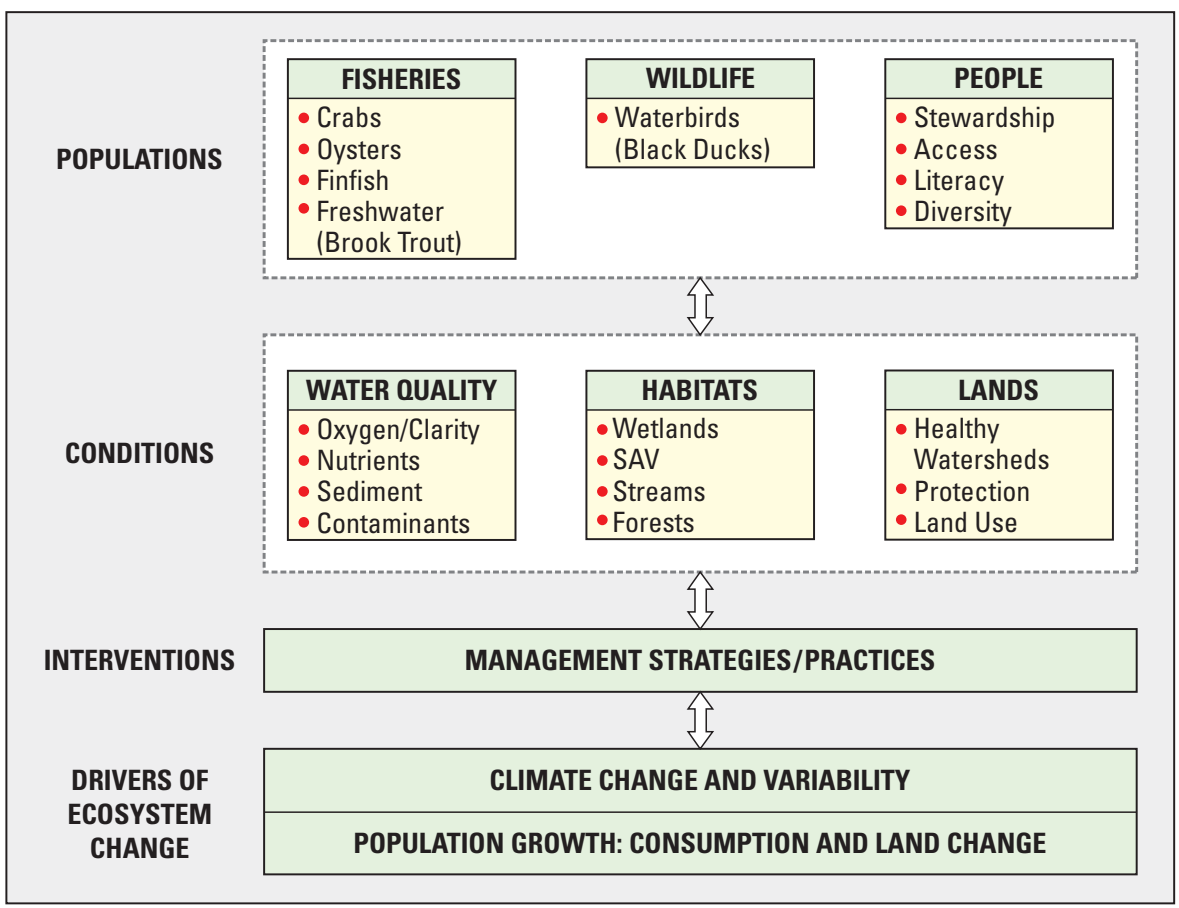

Figure 2. Conceptual diagram of Chesapeake Bay ecosystem. The major drivers of ecosystem change are population growth and climate variability, which have led to diminished watershed and estuary conditions, including poor water quality, degraded habitats, and loss of vital lands. Fish and wildlife populations have declined due to poor ecosystem conditions and management interventions are being implemented to restore the Chesapeake ecosystem.
Bay and its watershed. Although the CBP has had some notable successes over the years, improvements in the Chesapeake and other coastal ecosystems have been slow to occur due to effects of increasing human population and changing climatic conditions.

In May 2009, the President issued an Executive Order (EO 13508) for Chesapeake Bay Protection and Restoration to increase Federal Government support to address the challenges facing the Chesapeake Bay. The EO directed the Federal Government, including the U.S. Department of the Interior (DOI), represented by the National Park Service (NPS), the U.S. Fish \& Wildlife Service (FWS), and the U.S. Geological Survey (USGS), to expand its efforts and increase leadership to restore the Bay and its watershed. A Federal Leadership Committee (FLC) was established to ensure coordination of Federal activities and enhance consultation with states and stakeholders to align restoration efforts. In May 2010, the FLC released the approach to carry out the EO: Strategy for Chesapeake Bay Watershed Restoration and Protection (U.S. Environmental Protection Agency, 2010). The strategy has four essential goals and associated outcomes for the period 2010-2025: (1) restore clean water, (2) recover habitats, (3) sustain fish and wildlife, and (4) conserve land and increase public access (table 1). In its expanded role under the President's EO, the USGS was given the lead responsibility, in collaboration with the National Oceanographic and Atmospheric Administration (NOAA), to provide science, including addressing climate change, for all the goals in the EO. The EO resulted in enhanced restoration and conservation efforts, and has provided the foundation for the new Chesapeake Bay Agreement (hereafter known as the "Chesapeake Agreement.")

The Chesapeake Agreement, which was signed in June 2014, has goals and outcomes to be achieved by 2025. The Chesapeake Agreement has a vision of "an environmentally and economically sustainable Chesapeake Bay watershed, with clean water, abundant life, conserved lands and access to water, a vibrant cultural heritage, and a diversity of engaged citizens and stakeholders." More information on the Chesapeake Agreement is presented later in this chapter.

\section{Role of the USGS}

The USGS has the critical role to provide scientific information for the improved understanding and management of the Chesapeake Bay ecosystem. The USGS works with Federal, State, and academic science partners to provide research, monitoring, and to communicate implications to enhance ecosystem management both for the Bay and other National ecosystems. The USGS has been a partner in the CBP since its inception in 1983. The USGS expanded its Chesapeake Bay efforts in 1996 when it was selected as one of the USGS priority ecosystems. The USGS further expanded its activities in 2011 to meet the President's Chesapeake EO (Phillips, 2011). Since the EO was released, there have been several important changes in the CBP, DOI, and USGS: (1) The Chesapeake Agreement, (2) DOI leadership to carry out the Agreement, and (3) release of the USGS Mission Area (MA) science strategies. The USGS prepared this science strategy to address these three items. 


\section{Overview of USGS Chesapeake Science Strategy, 2015-2025}

The USGS Chesapeake Science Strategy is meeting the needs of selected items in the Chesapeake Agreement, supporting DOI priorities, and aligning with USGS MA science strategies. The USGS Chesapeake Science Strategy has four science themes (fig. 3) which will guide activities through 2025 (the timeline for the Chesapeake Agreement). Information from the science themes (middle column on fig. 3) will help inform ecosystem decision making (right column) for the Chesapeake Agreement and Partners, DOI priorities, and National ecosystem efforts. The Chesapeake science themes align with aspects of all the USGS MA science strategies (left column).

\section{New USGS Chesapeake Bay Science Themes and Objectives}

The USGS Chesapeake science themes are:

- Provide science to support restoration, and conservation of fish, wildlife, and critical habitats.

- Characterize and explain changes in water quality, and its effect on freshwater and estuarine ecosystems.

- Assess and forecast effects of climate and land change on ecosystem conditions.

- Synthesize and provide information to support ecosystem management.

The new USGS Chesapeake Bay themes focus on biological species of greatest importance to the DOI in the Bay and its watershed. Theme 1 is addressing (1) freshwater fisheries, and (2) waterfowl and waterbirds, and their relation to supporting habitat including water-quality conditions (theme 2 ). Theme 3 focuses on the drivers of ecosystem change: land and climate change. Scientific findings and management implications will be summarized to improve ecosystem management (theme 4). Each theme has three associated objectives which address specific Chesapeake Agreement outcomes and align with USGS MAs (table 2). The USGS is emphasizing these themes and objectives in the Chesapeake watershed because:

- A primary mission of the DOI is to manage fish, wildlife, and lands on the "interior of the Nation".

- The majority of the stressors to the ecosystem are from land change and climate variability. These have led to degraded water-quality conditions, loss of habitat, and landscape change in the watershed that has also affected the estuary.

- Restoration and conservation activities are focused in the watershed so science is needed to help implement, monitor, and assess their effectiveness.
- The influence of landscape and watershed characteristics needs to be better understood to explain ecosystem conditions and change.

- It is important to the partners who are also addressing estuary shellfish and finfish population issues including the NOAA, states, and academic institutions.

\section{Addressing the Chesapeake Agreement}

The 10 goals in the Chesapeake Agreement are (1) sustaining fisheries, (2) vital habitats, (3) water quality, (4) toxic contaminants, (5) healthy watersheds, (6) land conservation, (7) public access, (8) stewardship, (9) environmental literacy, and (10) climate resiliency (table 2). There are 31 outcomes associated with the Goals, which have led Federal agencies (table 3) working with CBP partners to implement practices and provide science to address each one. The USGS has identified 10 Chesapeake outcomes as high-priority topics because of the Survey's unique capabilities and providing science leadership. The following summary describes how USGS science is supporting our high priority and other selected Chesapeake Agreement outcomes.

Brook Trout Outcome: USGS will provide decisionrelevant science for the CBP outcome to "restore and sustain naturally reproducing Brook Trout populations in Chesapeake headwater streams with an 8-percent increase in occupied habitat by 2025." USGS studies will focus on better understanding several factors that affect Brook Trout populations including: (1) the role of groundwater in sustaining stream temperatures, (2) the effects of climate and land change on elevated stream temperature and altered hydrology, (3) the competition of invasive species on Brook Trout populations, and (4) the effects of unconventional oil and gas development on Brook Trout populations and habitat. Federal agencies [U.S. Environmental Protection Agency (EPA), USGS, FWS, U.S. Forest Service (USFS)], working through the National Plan to address Unconventional Oil and Gas (UOG) drilling, will coordinate studies to assess the effects of land disturbance and fracking fluids on Brook Trout populations and associated stream conditions. The findings will help inform the Eastern Brook Trout Joint Venture (EBTJV), FWS, and State partners so they can prioritize and assess actions to restore Brook Trout and account for other threats to their populations and habitat.

Black Ducks Outcome: USGS science is supporting decision making for the CBP outcome to "enhance and preserve restoring wetland habitats for wintering population of 100,000 Black Ducks, a species representative of the health of tidal marshes." The USGS will improve the understanding of factors affecting Black Duck populations including (1) climate change effects on coastal wetlands, and (2) food availability for Black Ducks near FWS Refuges. USGS is also looking at the ability of near shore habitat to support selected 


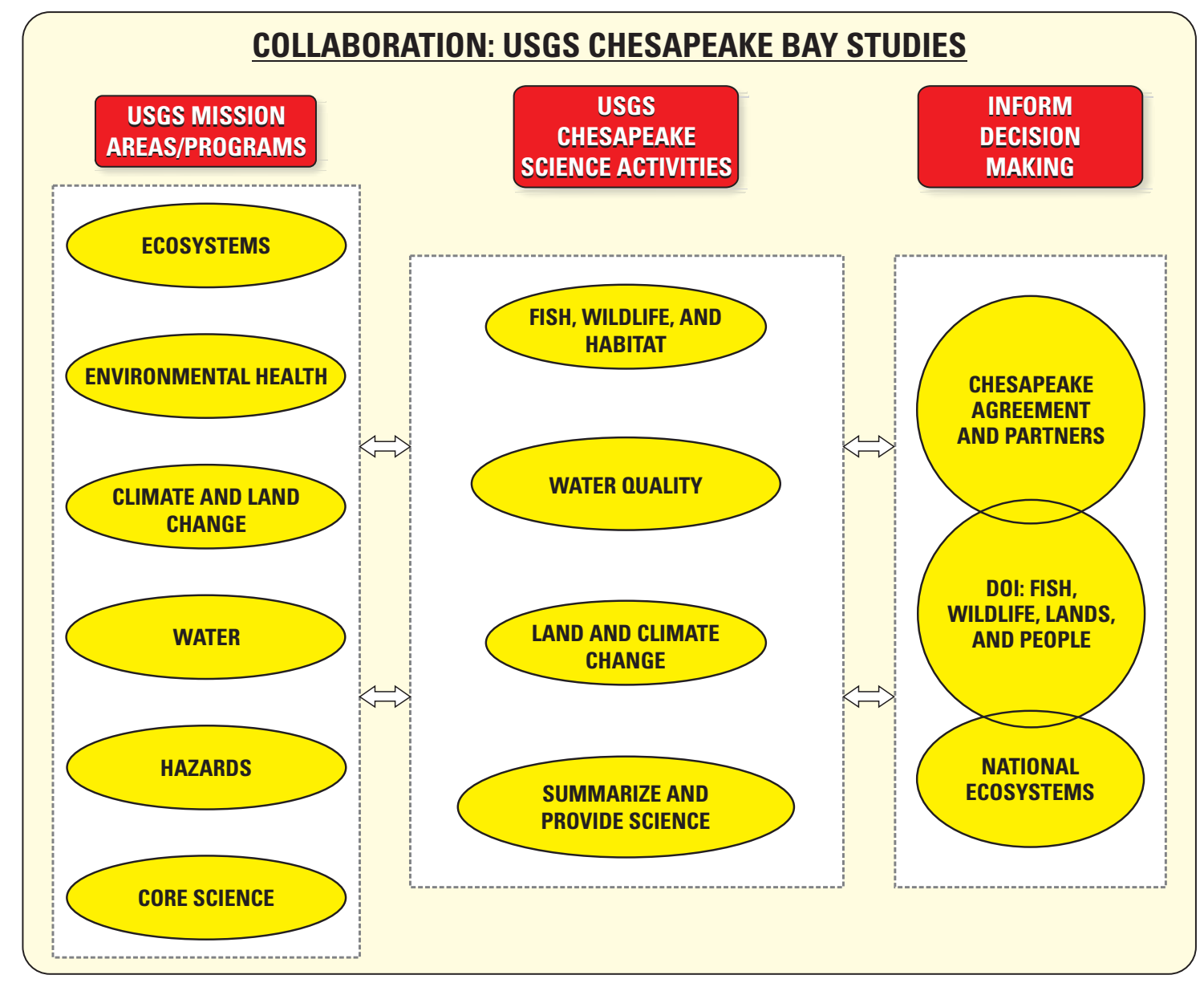

Figure 3. Relation between U.S. Geological Survey (USGS) Mission Areas, Chesapeake Bay science themes, and decision-making entities. The USGS Chesapeake Science activities (middle column) will inform decision makers (right column) for the Chesapeake Bay Program partners, U.S. Department of the Interior (DOI), and other national ecosystem stakeholders. The Chesapeake Bay science themes align with aspects of all the USGS Mission Area strategies (left column).

waterbirds through studies of (1) land development effects on habit fragmentation and shoreline disturbance, and (2) habitat restoration and recovery of waterbirds. The results will inform the Black Duck Joint Venture (BDJV), Atlantic Coast Joint Venture (ACJV), FWS, and State partners so that they can develop and assess actions to restore wetland and near shore habitats to support Black Ducks and other waterfowl.

Wetlands Outcome: USGS will conduct monitoring and research on both coastal and nontidal wetlands to address the CBP outcome "to increase capacity of wetlands to provide water quality and habitat benefit throughout the watershed." USGS studies of coastal wetlands are closely related to defining habitat conditions for Black Ducks and waterbirds (see Black Ducks Outcome). Additional USGS coastal wetlands efforts include (1) monitoring relative sea-level rise near Blackwater National Wildlife Refuge and other coastal wetlands, (2) assessing long-term changes in wetlands and the effects of storm surge, and (3) modeling marsh migration due to sea-level rise and land-use change. Information from coastal wetland studies will help inform FWS and states working to restore coastal wetlands. USGS is also involved in studies of freshwater wetlands with research on the natural water-quality functions of wetlands, and on their ability to provide waterquality benefits. This research on both natural and created and restored wetlands helps with water-quality management actions for the Total Maximum Daily Load (TMDL). Finally, the USGS will use the Chesapeake Land Change Model to predict areas where development, along with climate change, may cause loss of wetlands. The findings will be used by DOI land managers [FWS, NPS, and Bureau of Land Management (BLM)] to consider threats from climate and land change as they plan and implement wetland restoration activities.

Toxic Contaminant Research Outcome: USGS is leading the research activities for the CBP outcome to "increase our understanding of the impacts and mitigation options for toxic contaminants." USGS will focus activities on (1) 
Table 2. Relation between U.S. Geological Survey (USGS) Chesapeake Science Themes, Objectives, Mission Areas, and Outcomes of Chesapeake Agreement.

[CBP, Chesapeake Bay Program; SAV, submerged aquatic vegetation; WIP, Watershed Implementation Plan]

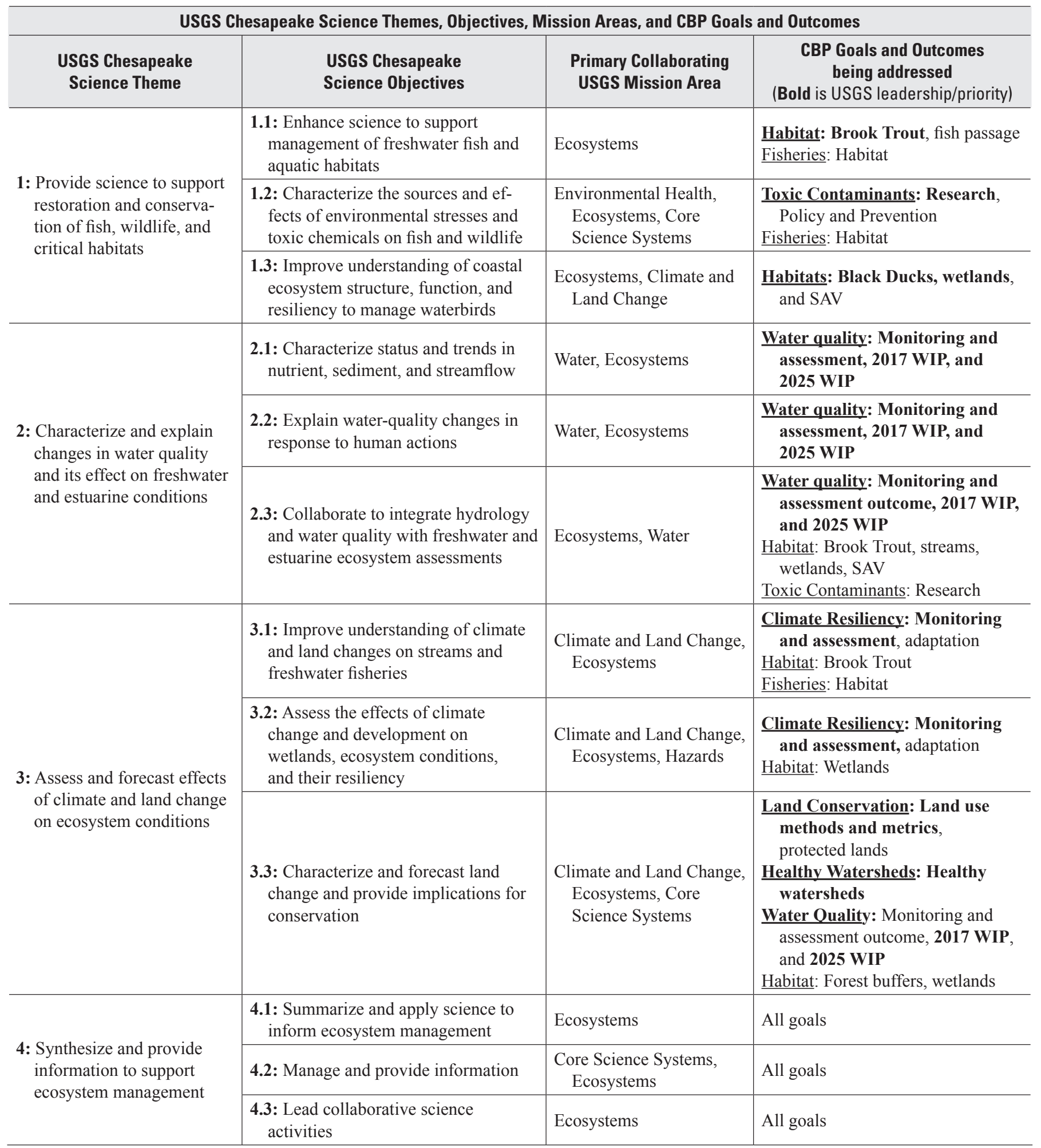


Table 3. Chesapeake Agreement, 2014-2025—Goals, Outcomes, and Lead Federal Agencies.

[NOAA, National Oceanic and Atmospheric Administration; USACE, U.S. Army Corps of Engineers; DOI, U.S. Department of the Interior; FWS, U.S. Fish \& Wildlife Service; USGS, U.S. Geological Survey; USFS, U.S. Forest Service; EPA, U.S. Environmental Protection Agency; NPS, National Park Service;

WIP, Watershed Implementation Plan]

\begin{tabular}{|c|c|}
\hline $\begin{array}{l}\text { Chesapeake Agreements Goals and } \\
\text { Supporting Outcomes, 2014-2025 }\end{array}$ & $\begin{array}{l}\text { Lead for Federal Agencies } \\
\text { (with collaboration with State and Local Partners) }\end{array}$ \\
\hline \multicolumn{2}{|c|}{ Sustainable Fisheries Goal } \\
\hline Blue Crab Abundance & NOAA \\
\hline Blue Crab Management & NOAA \\
\hline Oyster & NOAA, USACE \\
\hline Forage Fish & NOAA \\
\hline Fish Habitat & NOAA, DOI (FWS/USGS) \\
\hline \multicolumn{2}{|c|}{ Vital Habitats Goal } \\
\hline Wetlands & DOI (FWS/USGS) \\
\hline Black Duck & DOI (FWS/USGS) \\
\hline Stream Health & DOI (FWS/USGS) \\
\hline Brook Trout & DOI (FWS/USGS) \\
\hline Fish Passage & FWS, NOAA \\
\hline Submerged Aquatic Vegetation (SAV) & EPA, FWS \\
\hline Forest Buffer & USFS \\
\hline Tree Canopy & USFS \\
\hline \multicolumn{2}{|c|}{ Water-Quality Goal } \\
\hline 2017 WIP & EPA \\
\hline 2025 WIP & EPA \\
\hline Water-Quality Standards Attainment and Monitoring & EPA, USGS \\
\hline \multicolumn{2}{|c|}{ Toxic Contaminants Goal } \\
\hline Toxic Contaminant Research & DOI (USGS/FWS) \\
\hline Toxic Contaminant Policy and Prevention & EPA \\
\hline \multicolumn{2}{|c|}{ Healthy Watersheds Goal } \\
\hline Healthy Watersheds & EPA, DOI (USGS/FWS) \\
\hline \multicolumn{2}{|c|}{ Stewardship Goal } \\
\hline Citizen Stewardship & NPS \\
\hline Local Leadership & EPA \\
\hline Diversity & EPA, DOI (NPS) \\
\hline \multicolumn{2}{|c|}{ Land Conservation Goal } \\
\hline Protected Lands & NPS \\
\hline Land-Use Methods and Metrics Development & USGS \\
\hline Land-Use Options Evaluation & EPA \\
\hline \multicolumn{2}{|c|}{ Public Access Goal } \\
\hline Public Access Site Development & NPS \\
\hline \multicolumn{2}{|c|}{ Environmental Literacy } \\
\hline Student & NOAA, DOI (FWS/NPS/USGS) \\
\hline Sustainable Schools & NOAA \\
\hline Environmental Literacy Planning & NOAA \\
\hline \multicolumn{2}{|c|}{ Climate Resiliency } \\
\hline Monitoring and Assessment & DOI (USGS/FWS), NOAA \\
\hline Adaptation & USACE, NOAA \\
\hline
\end{tabular}


understanding the influence of contaminants degrading the health, and contributing to the mortality of fish and wildlife, and (2) documenting the occurrence, concentrations, and sources of contaminants including EDCs. The USGS is also addressing the potential relation between nutrients, sediment, and toxic contaminants in degrading the health of fisheries. The findings from these studies will support the development of strategies for contaminants to be addressed in the CBP outcome for toxic contaminant policy and prevention. The findings will inform EPA and the states in the watershed to consider the potential for nutrient reduction and sediment practices that will also reduce toxic contaminants.

\section{Watershed Implementation Plan (WIP) Outcomes:}

USGS studies inform management approaches to carry out the CBP outcomes "to have nutrient and sediment practices and controls in place to achieve the Bay's dissolved oxygen, water clarity/submerged aquatic vegetation (SAV), and chlorophyll a standards as articulated in the Bay TMDL." One outcome is to have 60 percent of practices in place by 2017 with the other outcomes to have all practices in place by 2025 . USGS will lead efforts to (1) provide land cover and change information to improve water-quality models, and (2) enhance watershed models used to help inform the 2017 WIP outcome and practices to reduce nutrient and sediment loads. USGS is also leading efforts to measure and explain water-quality change, which will help inform the 2017 WIP outcome and assess progress toward the TMDL (see next outcome).

Water-Quality Standards Attainment and Monitoring Outcome: USGS is leading efforts to address the CBP outcome to "improve the capacity to monitor and assess effects of management practices being undertaken to implement the Bay TMDL and improve water quality." USGS will lead a coordinated monitoring effort with EPA and the jurisdictions to compute nutrient and sediment loads in the Bay watershed and help assess the effects of management actions. The USGS will work with partners to explain nutrient and sediment changes in the watershed and work with scientists measuring water-quality standards attainment in tidal waters to improve the understanding of ecosystem response to restoration efforts. These results will provide information for TMDL milestone assessments (every 2 years) and contribute to the Midpoint Assessment (2017) and Final Evaluation of the TMDL (2025). EPA and partner jurisdictions use these results to make adjustments to management practices.

Climate Monitoring and Assessment Outcome: The USGS is providing leadership for partners to collaborate on the CBP outcome to "continuously monitor and assess the trends and likely impacts of climatic change and sea-level conditions on the Bay ecosystem, including the effectiveness of restoration and protection policies, programs, and projects." USGS will conduct studies to address the potential effects of climate and land change for three primary topics: (1) freshwater fisheries and streams, (2) coastal habitat supporting waterfowl, and (3) DOI lands and resources. The results of the USGS studies and other partner efforts will be used by DOI (FWS, NPS, and BLM) to develop climate adaptation strategies for DOI land and other partners to consider the potential effects of climate change on conservation and restoration activities.

\section{Land-Use Methods and Metrics Development} Outcome: The USGS will lead the effort, through collaboration with CBP partners, for CBP outcomes for "monitoring land change that can be used to help assess the impacts of land conversion on water quality, healthy watersheds, and communities." The USGS will contribute high-resolution, land-cover and elevation data that complements data being collected by Federal, State, and local entities across the watershed. The information will allow the USGS to develop the methodology for assessing landscape change and work through the CBP land cover workgroup, to finalize the method by 2016 . USGS will coordinate subsequent updates of land cover every $2-5$ years and develop approaches to quantify the impacts of land conservation. The results will support efforts led by the NPS to protect an additional 2 million acres in the Bay watershed by 2025 (protected lands outcome) and used by states to protect existing Healthy Watersheds (see next outcome).

Healthy Watersheds Outcome: The USGS is coordinating efforts to carry out the CBP outcome to sustain " 100 percent of the state-identified currently healthy watersheds." The USGS is working with states to understand the threats to healthy watersheds. USGS will use the Chesapeake Land Change Model to forecast areas where development will increase so states can assess the vulnerability of healthy watersheds and develop strategies to continue their protection. USGS forecasts of land development will also inform the CBP land protection outcome and identify areas being considered for protection that may be vulnerable to land and climate change.

USGS is also contributing to these CBP outcomes:

- Fish habitat: USGS is conducting research on habitat requirements of freshwater fisheries including Brook Trout, freshwater mussels, American Shad, and American Eel. Our research will contribute to a better understanding of the effects of urbanization, water quality, climate change (temperature and freshwater flow) and oil, gas, and mineral extraction of the habitats for species listed above.

- Fish passage: USGS is contributing expertise on fish passage implementation and relation to Brook Trout and other species listed in fish habitat.

- Stream health: USGS is helping to development of metrics to measure the multiple facets of stream health. We are also contributing to understanding functional lift from stream restoration projects, including a 
literature synthesis to document response of stream ecological conditions from restoration projects and enhanced monitoring.

- Riparian forest buffers: USGS is contributing to targeting for benefit for Brook Trout and water quality and helping with improved tracking using 1-2 meter high-resolution imagery being developed by CBP and USGS.

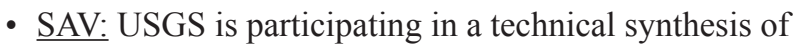
SAV and application of selected results to restore and conserve SAV.

\section{Providing Science for DOI Partners}

The Chesapeake Agreement aligns well with the DOI mission to manage and protect America's natural resources and heritage based on sound science (U.S. Department of the Interior, 2014). Given the relevance to the DOI mission, the FWS, USGS, and NPS have been designated as the Federal leaders (or coleaders) for 7 of the 10 goals and many of the associated 31 outcomes (table 3 ). The scientific findings produced by the USGS are used by Chesapeake Bay partners to manage fish and wildlife, improve habitats, restore water quality, and conserve lands. In the Chesapeake Bay, there is close collaboration among the DOI Bureaus. For example, the USGS and the FWS are teaming to understand the factors affecting freshwater fisheries and stream conditions to help restore Brook Trout and other sentinel aquatic species. The effects of toxic contaminants on fish and wildlife are being assessed by the USGS and FWS so partners can enhance efforts to improve water quality. The USGS and FWS are addressing the "carrying capacity" of wetlands to support waterfowl populations. Finally, the USGS is providing projections of land development and sea-level rise so that the DOI and other partners can develop adaption strategies to provide more resilient lands and habitats. The findings from Chesapeake Science activities enhance the understanding of processes affecting large ecosystems and are also applied to better manage additional areas across the Nation that are important to the DOI, such as San Francisco Bay Delta, Florida Everglades, Great Lakes, Gulf of Mexico, and Puget Sound.

\section{Collaborating with the USGS Mission Areas}

The complexity of the Chesapeake Bay ecosystem requires the USGS to have an interdisciplinary science approach, in coordination with other science providers, to inform a broad base of decision making. The Chesapeake activities span all six USGS MA strategies and contribute to one-half of the associated science goals (table 4). A priority of the Chesapeake Strategy is to have increased emphasis on addressing the health of fish and wildlife populations, as they are the major biological endpoints for the Chesapeake restoration efforts. Research includes a focus on supporting habitats and major stressors because this is an emphasis of the Chesapeake Agreement. The research in the Chesapeake is part of a national effort to understand ecosystems and the effectiveness of large scale restoration efforts.

\section{Cross-Cutting Science Questions}

The structure and function of biological communities of the Bay and its watershed are extremely complex and affected by a variety of stressors and physical conditions. To better define the issues that need to be addressed, the USGS has developed science questions for each science theme and crosscutting questions. The cross-cutting questions define some of our most important science challenges and identify where multiple disciplines and collaborators are needed to address an issue. The USGS investigators under our themes will improve information to help achieve many of the outcomes in the Chesapeake Agreement. Addressing the cross-cutting questions will provide an understanding of how restoration efforts could benefit multiple outcomes. Each of these questions was developed based on the unique capabilities of USGS scientists as well as critical needs identified by the management communities. A brief discussion of each question follows.

- How do land and climate change affect freshwater fish communities and habitats?

Land and climate changes are expected to adversely affect aquatic ecosystems and conditions for Brook Trout and other freshwater species. The major factors include increased loading of sediment, nutrients, and contaminants; changes in runoff and flow; increased water temperatures; and greater vulnerability to invasive species. These effects will challenge efforts to restore and sustain Brook Trout populations, which are sensitive to temperature changes, and species expected to migrate further into the watershed as fish passage efforts are implemented.

This question has emphasis on assessing and forecasting changes in stream conditions (especially hydrology and temperature) because of land and climate change. Activities associated with this cross-cutting question include assessing Brook Trout population responses to streamflow and temperature history to develop spatial occupancy and abundance models; developing fine-scale spatial models of stream habitat sensitivity to air temperature and precipitation; integrating analysis of flow and temperature for Brook Trout habitat and population dynamics; and forecasting stream habitat and Brook Trout vulnerability to climate, land use, and land-cover change. The land-cover change activities would focus on both predictions of land development and potential effects of unconventional oil and gas development in the Chesapeake Bay watershed.

- What are the relationships among land use, water quality, contaminants, and the health of fish and wildlife? 
Table 4. U.S. Geological Survey (USGS) Mission Areas and Associated Science Strategy Goals.

[Bold terms are goals where Chesapeake Bay activities have the most relevance]

\section{Ecosystems Mission Area}

(1) Improve understanding of ecosystem structure, function, and processes.

(2) Advance understanding of how drivers influence ecosystem change.

(3) Improve understanding of the services that ecosystems provide to society.

(4) Develop tools, technologies, and capacities to inform decision making about ecosystems.

(5) Apply science to enhance strategies for management, conservation, and restoration of ecosystems. Environmental Health Mission Area

(1) Identify, prioritize, and detect contaminants and pathogens of emerging environmental concern.

(2) Reduce the impact of contaminants and pathogens on the environment, fish and wildlife, domesticated animals, and people.

(3) Discover the complex interactions between, and combined effects of, exposure to contaminants and pathogens.

(4) Prepare for and respond to the environmental impacts and related health threats of natural and anthropogenic disasters.

Water Mission Area

(1) Provide information on the amount and quality of water in all components of the water cycle.

(2) Advance our understanding of processes that determine water availability.

(3) Predict changes in quantity and quality in response to changing climate, population, land use, and management scenarios.

(4) Anticipate and respond to water-related emergencies and conflicts.

(5) Deliver timely data, analyses, and decision support tools to support water-resources decisions.

Climate and Land-Use Change Mission Area

(1) Rates, causes, and impacts of past global changes.

(2) Global carbon cycle.

(3) Biogeochemical cycles and their coupled interactions.

(4) Land-use and land-cover change rates, causes, and consequences.

(5) Droughts, floods, and water availability under changing land-use and climate conditions.

(6) Coastal response to sea-level rise, climatic change, and human development.

(7) Biological responses to global change.

\section{Core Science Systems}

(1) Provide research and data to understand the critical zone.

(2) Expand applications of USGS research through scientific services.

(3) Conduct analysis and synthesis to improve coverage, quality, usability, and timeliness of information.

Hazards

(1) Enhanced observations.

(2) Fundamental understanding of hazards and impacts.

(3) Improved assessment products and services.

(4) Effective situational awareness.

Sustaining fisheries in the Bay and its watershed is an important goal of the Chesapeake Agreement. The health of fish has been degraded and fish kills are becoming more widespread in the watershed, which is raising significant public concern. To help restore conditions for fish in the watershed, we need to better understand the complex array of stressors to which they are exposed, including poor water quality, physical habitat alterations, food-web changes, pathogens and parasites, and climatic variability. Fish species vary in their sensitivity to stressors so using their responses as indicators of ecosystem conditions can provide important insights into management implications. Collaboration of science activities will be conducted to better understand the following: (1) the sensitivity of fish species to differing environmental conditions, (2) the effects of contaminants on fish health, (3) the sources and pathways of contaminants, (4) risk assessment modeling for predicting threats to selected species from different contaminant groups, (5) relation of nutrients to pathogens 
and bacteria in streams, and (6) alterations in physical conditions that can affect spawning habitats. The science generated to address this question will contribute to better understanding how management and land-use practices can provide benefits to freshwater fish through restoring stream habitat and waterquality conditions.

- How are coastal wetland and the resultant carrying capacity for waterbirds affected by changing climate and land use?

Coastal wetlands around the Bay are being lost to sea-level rise and land development. The wetlands provide important habitat for waterbirds and water-quality benefits to the Bay. This question looks at the stress of land development and sea-level rise on coastal wetlands, and helps assess the effect on carrying capacity for waterbirds. Supporting activities include (1) bioenergetics modeling of refuges for wintering Black Ducks, (2) freshwater wetland loss, (3) sea-level rise and wetland migration, (4) long-term changes in sea level and potential effects on marshes, and (5) potential development and loss of marshes. The findings will contribute to informed placement and types of wetland restoration to support wintering waterbirds, including the outcome to have 100,000 Black Ducks wintering each year.

- How is the water quality of rivers and estuaries responding to restoration actions, and changing land use?

Practices to reduce nutrients and sediment are the foundation of the new Bay TMDL put in place to improve water-quality conditions in the Bay. Information is needed to better understand how water quality is responding to these practices in the watershed, and improving dissolved oxygen and water-clarity conditions in the estuary. Understanding water-quality response is complicated by multiple factors including changes in land use, landscape characteristics affecting the fate and transport of nutrients and sediment (contributing to "lag times"), and climate variability. Activities to address this question include (1) field and modeling studies of major source sectors (agricultural and suburban areas) of nutrients and sediment, (2) developing histories of land change, and (3) improved tracking of management practices. Findings from this question will help inform implementation of practices for the TMDL and attainment of water-quality standards. The findings from this question will also help inform restoration activities for fisheries and their habitats.

- What are some of the best opportunities to align science to support the new CBP outcomes?

The new Chesapeake Agreement contains 10 goals and 31 outcomes. The CBP partners are looking for strategic and innovative approaches to identify actions that can provide benefits to multiple outcomes. For example, riparian forest buffers reduce nutrient and sediments into a stream but can also help sustain stream temperatures needed for Brook Trout. The USGS will work with partners to collaborate on monitoring, modeling, and synthesis activities toward supporting science for outcomes in the Chesapeake Agreement. Knowledge gained from our cross-cutting questions will be summarized to help inform the Goal Teams of key opportunities. 


\section{Science Theme 1: Enhance Science to Support Restoration and Conservation of Fish, Wildlife, and Critical Habitats}

Restoring and protecting populations of fish and wildlife is a fundamental priority of the DOI and the Chesapeake Agreement. Fisheries and waterfowl are two key biological communities highlighted in the Chesapeake Agreement and are being addressed through the sustainable fisheries, vital habitats, and toxic contaminants goals and selected outcomes (see highlight box for outcomes).

- Sustainable fisheries-Protect, restore, and enhance finfish, shellfish, and other living resources, their habitats and ecological relationships to sustain all fisheries and provide for a balanced ecosystem in the watershed and Bay. Selected outcomes are focused on assessing fish habitat.

- Vital habitats-Restore, enhance, and protect a network of land and water habitats to support fish and wildlife, and to afford other public benefits, including water quality, recreational uses, and scenic value across the watershed. Selected outcomes are focused on improving stream health, Brook Trout, fish passage, wetlands, Black Ducks, and submerged aquatic vegetation.

- Toxic contaminants-Ensure that the Bay and its tributary rivers are free of the effects of toxic contaminants on living resources and human health. There are outcomes on research and policy/prevention.

To meet the science needs of goals and associated outcomes, USGS scientists and partners with expertise in freshwater fisheries, fish health, contaminant biology, toxic substances hydrology, and waterfowl will collaborate with experts in land use, hydrology, water quality, and climate change to address three objectives:

-1.1 Enhance science to support management of freshwater fish and aquatic habitats.

- 1.2 Characterize the sources and effects of environmental stresses and toxic chemicals on fish and wildlife.

- 1.3 Improve understanding of coastal ecosystem structure, function, and resiliency to manage waterbirds.

The Chesapeake Bay activities meet the goals of, and are supported by, several USGS MAs:

- Ecosystem MA goals addressed include: (1) improve understanding of ecosystem structure, function, and processes; (2) develop tools, technologies, and capacities to inform decision making about ecosystems; and (3) apply science to enhance strategies for management, conservation, and restoration of ecosystems.
Work under this objective also addresses USGS Fisheries and Ecosystem Program priorities related to stream health, fish migration and passage, headwater fisheries, and landscape science.

- Water MA goal related to predicted changes in quality and quantity in response to climate and land changes.

- Climate and Land Change MA goals related to land-use and cover change rates, and biological responses to global change.

- Environmental Health MA goals to (1) identify, prioritize, and detect chemicals and pathogens of emerging concern; (2) reduce the impact of contaminants on the environment, fish, wildlife, and humans and (3) discover the complex interactions and combined effects of contaminants and pathogens. The research approach is consistent with the USGS National EDC Research Framework being carried out through the Contaminants Biology and Toxic Substances Hydrology Programs.

- Core Science System MA goal to expand applications of USGS research through scientific services.

\section{Objective 1.1 Enhance Science to Support Management of Freshwater Fish and Aquatic Habitats}

\section{Needs and Questions}

With over 100,000 streams and rivers in the Chesapeake Bay watershed, sustaining and restoring freshwater fish and associated aquatic habitats is a high priority of the Bay Program partners, State resource agencies, and the public. Harvesting pressure, fish barriers, invasive species, disease, and habitat loss and degradation from changes in land use and land cover have caused significant declines in many important aquatic species. Fish are an integral part of the aquatic ecosystem and as such contribute significantly to the ecological services of streams, rivers, and ultimately the Bay itself.

Brook Trout are identified in the President's EO as a high-priority species based on their ecological, commercial, and recreational significance and they are also an outcome in the new Chesapeake Agreement. They are an integral part of the headwater stream ecosystem and in addition to the ecological impacts, declining Brook Trout and other fish populations have led to lost economic revenue and recreational fishing opportunities in the Bay's headwaters. The planning and management actions undertaken for Brook Trout conservation and restoration will also benefit other species in the headwater stream ecosystem and the overall ecological integrity of the Bay and its headwaters. 


\section{Science Theme 1 Addresses These Chesapeake Restoration Goals and Outcomes}

\section{Vital Habitats Goal}

Brook Trout Outcome: USGS will provide decision-relevant science for the CBP outcome to "restore and sustain naturally reproducing Brook Trout populations in Chesapeake headwater streams with an 8-percent increase in occupied habitat by 2025." USGS studies will focus on better understanding several factors that affect Brook Trout populations including: (1) the role of groundwater in sustaining stream temperatures, (2) the effects of climate and land change on elevated stream temperature and altered hydrology, (3) the competition of invasive species on Brook Trout populations, and (4) the effects of Unconventional Oil and Gas (UOG) development on Brook Trout populations and habitat. Federal agencies (EPA, USGS, FWS, USFS), working through the National Plan to address UOG drilling, will coordinate studies to assess the effects of land disturbance and hydraulic fracking fluids on Brook Trout populations and associated stream conditions. The findings will help inform the Eastern Brook Trout Joint Venture (EBTJV), FWS, and State partners so they can prioritize and assess actions to restore Brook Trout and account for other threats to their populations and habitat.

Black Ducks Outcome: USGS science is supporting decision making for the CBP outcome to "enhance and preserve restoring wetland habitats for wintering population of 100,000 Black Duck, a species representative of the health of tidal marshes." The USGS will improve the understanding of factors affecting Black Duck populations including (1) climate change effects on coastal wetlands, and (2) food availability for Black Ducks near FWS Refuges. USGS is also looking at the ability of near shore habitat to support selected waterbirds through studies of (1) land development effects on habitat fragmentation and shoreline disturbance, and (2) habitat restoration and recovery of waterbirds. The results will inform the Black Duck Joint Venture (BDJV), Atlantic Coast Joint Venture (ACJV), FWS, and State partners so that they can develop and assess actions to restore wetland and near shore habitats to support Black Ducks and other waterfowl.

Wetlands Outcome: USGS will conduct monitoring and research on both coastal and nontidal wetlands to address the CBP outcome "to increase capacity of wetlands to provide water quality and habitat benefit throughout the watershed." USGS studies of coastal wetlands are closely related to defining habitat conditions for Black Ducks and waterbirds (see Black Ducks Outcome). See water quality and climate and land change themes for additional USGS wetlands activities for this outcome.

\section{The USGS activities will also benefit these outcomes:}

Fish Habitat: Research on habitat requirements of freshwater fisheries including Brook Trout, freshwater mussels, American Shad, and American Eel. Better understand effects of urbanization, water quality, climate change (temperature and freshwater flow) and oil, gas, and mineral extraction of the habitats for species listed above.

Fish Passage: Contribute expertise on fish passage implementation and relation to Brook Trout and other species listed in fish habitat.

\section{Toxic Contaminant Goal}

Toxic Contaminant Research Outcome: USGS is conducting some of the principal field and laboratory studies in support of the toxic contaminant research outcome. Current activities are focused on understanding the influence of contaminants degrading the health, and contributing to the mortality of fish and wildlife. A companion activity is to document the occurrence, concentrations, and sources of contaminants including endocrine-disrupting compounds (EDCs). The findings from these studies will be support prioritization of adaptive strategies for the Policy and Prevention outcome being considered by the Water Quality Goal Team, which includes EPA, and the states in the watershed. 
In addition to Brook Trout, the Chesapeake Agreement has outcomes for restoring fish passage and improving fish habitat. The CBP is working to increase available habitat to support sustainable migratory fish populations in Chesapeake Bay freshwater rivers and streams. Key species include Alewife, Blueback Herring, American Shad, Hickory Shad, and American Eel. Increasing the amount of and access to suitable habitat are both necessary to sustain high quality fisheries in the Bay watershed.

Results from this research will directly support initiatives related to the following DOI goals: Protect America's Landscapes; Enhance Recreation and Visitor Experience; and Provide Science to Understand, Model, and Predict Ecosystem, Climate, and Land-Use Change (U.S. Department of the Interior, 2014). Products will help inform management decisions and monitoring designs specific to FWS trust resource responsibilities and National Parks in the Chesapeake Bay watershed.

The science questions, both cross-cutting and supporting, have been developed to further define the needs and help focus activities. The cross-cutting question is intended to better define the linkage between fish communities and a large array of factors including land use, land cover, invasive species, disease, and climate change: "How do land and climate changes affect fish communities, fish health, and freshwater habitats?"

The supporting science questions include:

- What are the independent and interactive effects of invasive species and thermal stressors on Brook Trout behavior and growth?

- What is the role of groundwater for Brook Trout habitat and resilience to climate change?

- Can risk assessment or spatial modeling approaches be used to assess ecological variables affecting populations of sensitive or indicator fish species, and other high priority fish?

- What are the effects of unconventional oil and gas development on fish and aquatic habitats?

- What is the adaptive potential for fish populations?

- What are the evolutionary and ecological processes regulating Brook Trout population dynamics and sustainability?

- What aspects of fish characteristics, environmental conditions, and passage designs affect successful barrier navigation by fish and Eels and effective monitoring programs?

\section{Anticipated USGS Activities}

An integrated research approach will be used to incorporate the hydrologic, geomorphic, physicochemical, and biological components of aquatic ecosystems in the watershed. The priority of this objective is enhanced understanding of Brook Trout populations and their habitats to support the outcomes in the Chesapeake Agreement. These activities will also inform the CBP outcomes for fisheries habitat, and fish passage. The anticipated activities include:

- Assessing Brook Trout population responses to streamflow, groundwater, and temperature history and modeling the interconnections. The types of models being considered are spatial abundance models and fine-scale spatial models of stream habitat sensitivity to air temperature and precipitation. The models will help facilitate integrated analysis of flow and temperature for Brook Trout habitat and population dynamics, evaluating the independent and interactive effects of invasive species and thermal stressors on Brook Trout behavior and growth, and forecasting stream habitat and Brook Trout vulnerability to climate and land-use and land-cover change. Products include Geographic Information System (GIS) maps and data layers, predictive habitat and Brook Trout models, workshops, reports, and journal publications that will help resource management partners identify options to mitigate the effects of climate and land-use change, and inform management decisions for conservation and restoration of Brook Trout habitat. The spatial and population models will also contribute to regional modeling efforts of Brook Trout population dynamics. A facilitated workshop on Brook Trout and regional temperature modeling will bring together scientists and managers to develop shared data sources, model guidance and application, and refine resource management objectives and science needs. This will help conservation partners identify important information gaps, better understand the factors affecting fish habitat, adaptive potential, and population persistence, and prioritize conservation and restoration activities.

- Assessments of effects of UOG will have some baseline data collection activities with most of the work associated with this issue related to national efforts to assess the potential effects of hydraulic fracking on habitat conditions. The USGS will also consider the CBP Scientific and Technical Advisory Committee (STAC) report about potential impacts of UOG development on the Bay watershed (Gottschalk and others, 2013) to plan potential activities with CBP partners.

- Activities assessing fish passage include the development of standardized assessment tools for fish passage evaluations, development of a fish passage database to provide a systematic, georeferenced source of data for 
all known upstream fish passage structures, and evaluating climate change impacts on swimming performance, energetics, and successful fish passage. Results will inform State and Federal agencies on the efficacy of current fish passages, improve passage designs, and the development of effective monitoring programs.

- Many of the current activities are interdisciplinary in nature and incorporate several aspects of the crosscutting question. We will also collaborate with the teams from the other themes to incorporate additional relevant information from those objectives necessary to address the cross-cutting question.

The majority of the Brook Trout work is being conducted at Shenandoah National Park, Catoctin Mountain Park, and the USGS Leetown Science Center laboratories in Kearneysville, West Virginia and Wellsboro, Pennsylvania (fig. 4). Results from these studies will be relevant to headwater streams and Brook Trout habitat throughout the Chesapeake Bay watershed.

\section{Science Partners}

These activities will be conducted in collaboration with a wide range of Federal, State, and university partners. These science partners include the Maryland Department of Natural Resources (MD DNR); the West Virginia Division of Natural Resources and Department of Environmental Protection; Pennsylvania Fish \& Boat Commission; Pennsylvania Department of Environmental Protection (PADEP); Pennsylvania Sea Grant (PA Sea Grant); NPS; FWS; North Atlantic, Appalachian, and South Atlantic Landscape Conservation Cooperatives (LCCs); North East Climate Science Center (NECSC); Eastern Brook Trout Joint Venture (EBTJV); the University of Massachusetts; West Virginia University; and the Pennsylvania State University.

\section{Objective 1.2 Characterize the Sources and Effects of Environmental Stresses and Toxic Chemicals on Fish and Wildlife}

\section{Science Needs and Questions}

The health of fish and wildlife has been adversely affected by a complex array of stressors to which they are exposed. The stressors include habitat (physical and chemical) alterations, food web changes, pathogens and parasites (opportunistic, emerging, invasive), climatic factors, and contaminants. Fish and wildlife species vary in their sensitivity to stressors and hence identifying sensitive species within individual watersheds/impaired ecosystems and utilizing their responses as indicators of various stressors are keys to understanding and ultimately mitigating their effects. In addition,

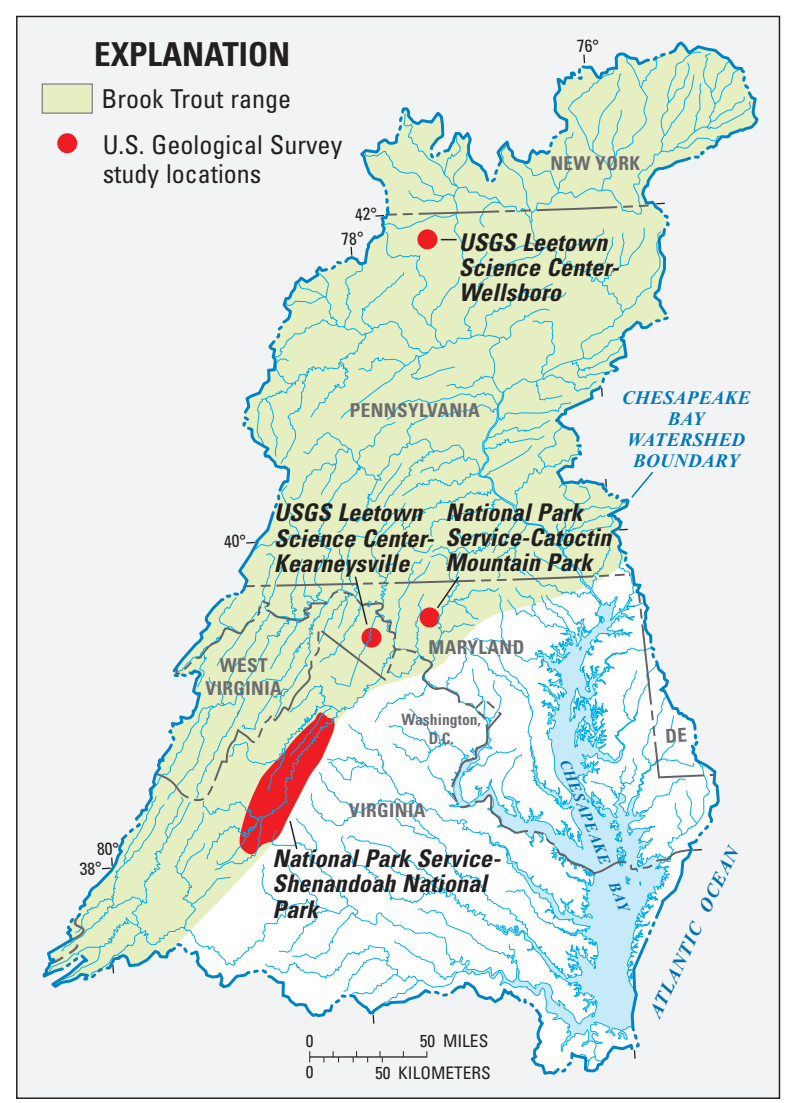

Figure 4. Brook Trout range and selected U.S. Geological Survey (USGS) study locations.

the tools, methodologies, and capacities developed can be utilized for additional species and geographic areas.

The Chesapeake Agreement has several outcomes related to improving conditions for fisheries: stream health and fish habitat, with the toxic contaminant outcomes focus on both fish and wildlife. Chemical contaminants, including legacy and chemicals of emerging concern, particularly EDCs, have had effects on fish and wildlife populations in the Chesapeake Ecosystem (U.S. Environmental Protection Agency and others, 2012). There is a toxic contaminant goal in the Chesapeake Agreement with two outcomes: (1) research to continually increase our understanding of the impacts and mitigation options for toxic contaminants and (2) policy and prevention to reduce the effects of contaminants on fish, wildlife, and human health. Understanding the sublethal, cumulative effects of complex mixtures of chemicals on reproductive success and general health and survival is necessary in developing management strategies. Identifying factors that influence species' susceptibility to toxic chemicals and EDC-related effects will identify the most at-risk fish and wildlife populations, as well as guide mitigation efforts to reduce potential impacts on sensitive populations. Exposures at discrete life stages of an organism can elicit different effects. Hence, research to better quantify the interactions between life history 
strategies and effects of contaminants is critical for developing likelihood-based risk models and ultimately population-level implications. Development of management strategies requires identification of sources, transport mechanisms, and exposure pathways. Documenting the extent of observed adverse effects together with spatial and temporal chemical concentrations will allow for the development of risk assessment models. The CBP outcomes will also help address the DOI priorities of building a landscape-level understanding of resources and the protection and restoration of aquatic species.

The science needs have further defined a cross-cutting question and associated supporting questions. The crosscutting question is: "What are the relationships among land use, water quality, contaminants, and the health of fish and wildlife?"

The supporting questions are:

- To what extent are the pathogens, parasites (and their intermediate hosts) affecting the health of fish populations and how do their populations relate to nutrients, climate change, and habitat quality?

- Are algal and cyanobacteria blooms adversely affecting the health of freshwater fishes?

- What is the relationship between the health of sensitive/indicator species and land use?

- How does habitat usage (tributary versus main stem) relate to fish health?

- What is the extent of adverse effects associated with exposure to toxic contaminants (including EDCs)?

- What are the important sources, transport, and exposure mechanisms of toxic contaminants (including EDCs) to fish and wildlife?

- Are there management practices (upgrades to wastewater treatment facilities, agricultural and urban Best Management Practices) that are effective at reducing certain important contaminants?

\section{Anticipated USGS Activities}

The research approach addresses the factors affecting the health and mortality of freshwater fisheries and wildlife. Given the interdisciplinary nature of the research, several USGS MAs are involved including Environmental Health, Ecosystems, Water, Climate and Land Change, and Core Science Systems. The emphasis is on addressing the CBP toxic contaminant goal and carrying out the USGS National EDC Research Framework and the associated Chesapeake Bay EDC research plan. The primary anticipated activities are:

- Addressing skin lesions, mortalities and reduced reproductive health of adult fishes including identifying the most important causes (pathogens, parasites) and contributing factors (nutrients, toxic/immunosuppressive/ EDCs), assessing the role of algal/cyanobacteria toxins (microcystin) and other products (phytoestrogens) on general and reproductive health, and developing gene expression markers and molecular pathogen techniques to better understand the mechanisms (disease resistance factors, hormone receptor activation, etc.) of observed effects.

- Better defining the associations among general and reproductive fish health indicators with agricultural land use, wastewater treatment facilities, nutrient concentrations, flow, and contaminant concentrations. A telemetry study was initiated in 2014 and will continue into 2015 to better understand how life history characteristics and land-use effects interact to influence the health of sensitive or high-priority fish populations.

- Identifying the factors (climatic, invasive species, nutrients) contributing to the proliferation of parasite and opportunistic pathogens associated with mortality of young-of-the-year bass by evaluating the distribution of diseased young bass, toxic contaminants that may be passed from mother (egg) to young bass, the proliferation of the benthic worms and snails that are parasite intermediate hosts, and the potential role of an invasive crayfish.

- The adverse effects of exposure to EDCs and other contaminants in fishes, together with chemical concentrations in water and sediment have been documented for over a decade. These results will be summarized and analyzed for temporal and spatial patterns and in terms of land use, protected lands, climatic and hydrological factors. A database and associated summary report and presentations to resource agencies and journal articles will be produced. This information will also be necessary for risk assessment and other models. There is little information on the effects of EDCs on aquatic-associated organisms such as amphibians and reptiles or birds that may use fish or other aquatic organisms as food. Studies are being developed to identify effects in wildlife, if present.

- Identify the sources (point and nonpoint) of these chemicals to the water and sediment in affected watersheds and associated land-use characteristics. Analyze data collected to document the temporal change in hormones, pesticides, and other contaminants in proximity to wastewater treatment plants (WWTPs). Reports to resource agencies and journal articles will be produced. Monitoring and analyzing temporal and spatial changes in hormones, pesticides, and other contaminants in agricultural watersheds will be an emphasis. These studies are done in conjunction with the biological effects monitoring. 
- Understanding the important transport and exposure pathways into organisms (i.e. through water, suspended sediment, maternally through the egg). Identification of key windows of exposure (fry, adult during recrudescence) and the hydrological, seasonal, or climatic factors significantly influencing the presence and (or) toxicity of individual chemicals and chemical mixtures will inform management implications.

- Developing advanced technologies and other tools to better understand mechanisms of effects (reduced reproductive success, immunomodulation, endocrine disruption) will include genomics, molecular pathology and other tools to determine the mechanisms of observed effects in both wild and laboratory-exposed organisms. These studies will also identify the physiological, behavioral, or life history characteristics that contribute to differential species sensitivities.

- Determining the geographic extent of complex mixtures with specific modes of action (i.e. total estrogen, androgen, thyroid, glucocorticoid receptor activation). Water samples will be surveyed utilizing in vitro cell-based screening tools, in conjunction with the water quality theme at showcase and nontidal network sites, to assess land-use and management practices on the presence of hormone activity. An effects-directed analysis can then be used to identify candidate chemicals or chemical classes.

Most of the current and planned activities are interdisciplinary in nature, incorporate aspects of the cross-cutting questions, and build on one another. The studies will occur at a series of sites with different land-use characteristics. We will also collaborate with the teams from the other themes to incorporate additional relevant information from those objectives necessary to address cross-cutting questions. Activities (2014-2019) addressing general and reproductive fish health are primarily focused throughout the Potomac and Susquehanna River drainages (fig. 5). Other areas of the Chesapeake watershed, such as the James, Rappahannock, Choptank, South, Severn, and Patuxent Rivers have received less monitoring and assessment but are being considered for additional work.

\section{Science Partners}

These activities are conducted in collaboration with a wide range of Federal, State, and university partners including MD DNR; West Virginia Division of Natural Resources and Department of Environmental Protection; Pennsylvania Fish \& Boat Commission; PADEP; PA Sea Grant; NPS; FWS, the National Institutes of Health, National Cancer Institute; Potomac and Shenandoah Riverkeepers, West Virginia University, Hood College, and the Pennsylvania State University.

\section{Objective 1.3 Improve Understanding of Coastal Ecosystem Structure, Function, and Resiliency to Manage Waterbirds}

\section{Science Needs and Questions}

This objective provides much needed science for resource managers and land conservation agencies to understand the influences of coastal ecosystem structure, function, and resiliency on waterbird species, such as the American Black Duck. The science will address two primary Chesapeake Agreement outcomes: (1) Black Ducks and (2) wetlands. Science is needed to inform placement and types of wetland to support wintering waterbirds, with a specific outcome for having 100,000 Black Ducks. The science will also benefit information needed for the SAV outcome. Waterfowl and their habitats is a priority for DOI and the science will help inform regional efforts for management along the Atlantic Flyway.

The science questions focus on the factors affecting Black Duck populations and their supporting habitats, which are primarily wetlands. The cross-cutting science question being addressed is:

"How are coastal wetlands and their carrying capacity for waterbirds affected by changing sea level and land use?"

The supporting science questions being addressed are:

- What are the present food availability, density, and dispersion for wintering Black Ducks in high marsh, low marsh, mudflat, SAV, and freshwater habitats within the National Wildlife Refuges?

- How much energy is obtained by wintering Black Ducks as the top prey items (killifish, salt marsh snail, horned pondweed, widgeon grass) vary in densities?

- What is the present energetic carrying capacity of high marsh, low marsh, mudflat, SAV, and freshwater habitats on the wildlife refuges for wintering Black Ducks?

- Are there avian flu viruses in migratory waterfowl that use the Atlantic Flyway?

- Assess the potential for bivalves, suspended sediment and sediment to sequester or facilitate transmission of flu viruses or other pathogens.

- How does shoreline type influence water quality, SAV abundance, fish, macroinvertebrates, and waterbird abundance and density?

- Are living shoreline efforts aiding in the recovery of these factors?

- How does habitat creation or modification on Bay islands impact breeding waterbirds? 


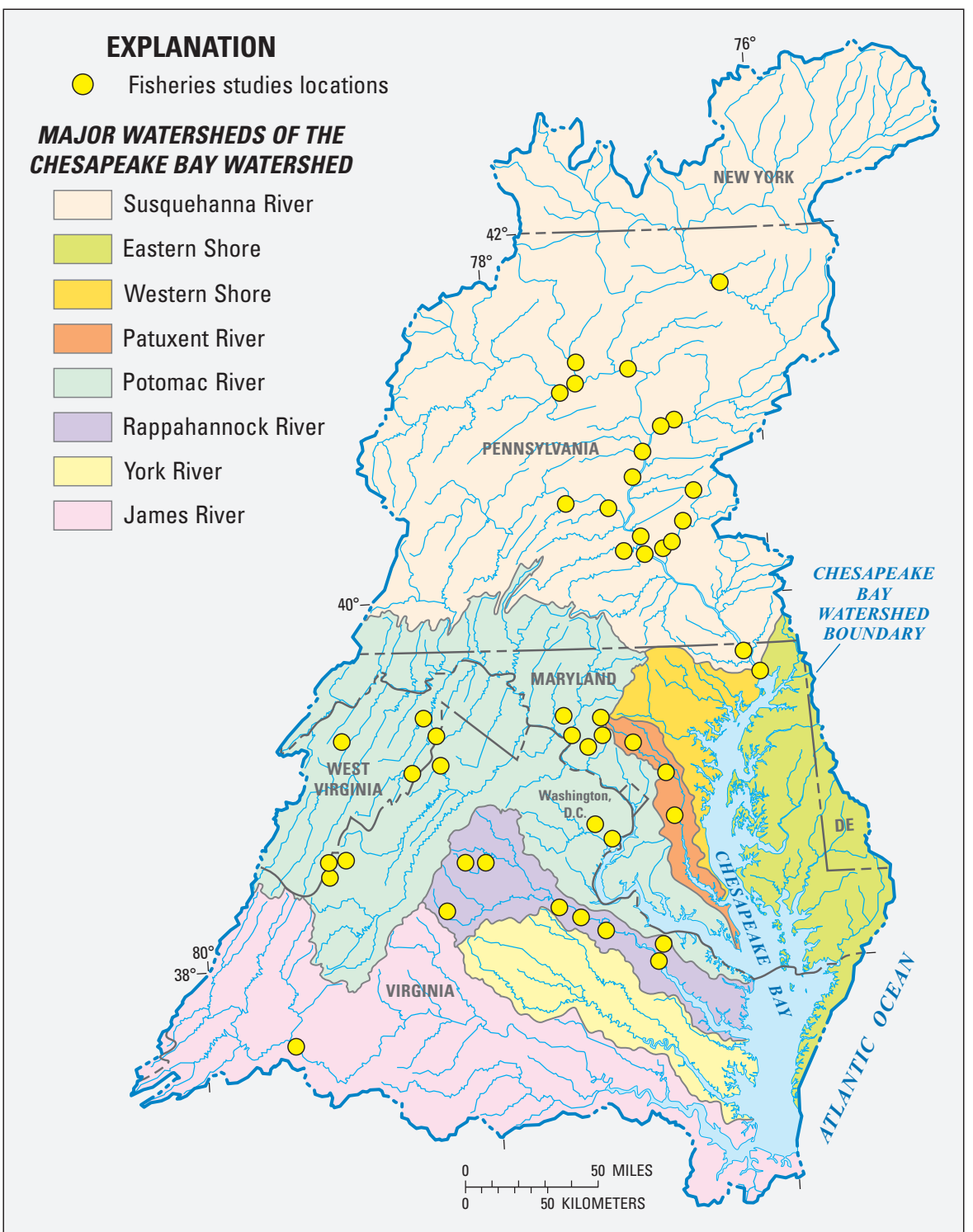

Figure 5. U.S. Geological Survey (USGS) fish health study locations. The USGS will collaborate with partners to enhance efforts to address environmental stresses, including the effects of toxic contaminants and associated endocrinedisrupting compounds (EDCs), on fish and wildlife in the Bay watershed.
- What is the nesting productivity for waterbirds nesting on these restored island habitats?

\section{Anticipated USGS Activities}

This objective addresses several goals of Ecosystems and the Climate and Land Change MAs. Potential USGS activities include:

- Quantify and model the relationship between prey dispersion and availability found on five habitat types (high marsh, low marsh, mudflat, SAV, and freshwater) key to wintering Black Ducks, and the physiology and energetics of the duck to determine carrying capacity of habitat types in the Chesapeake Bay for wintering
Black Ducks. Initial focus is on FWS Refuges near the Bay (fig. 6). There is potential to expand energetic carrying capacity analysis to other coastal wetland habitats of the Bay.

- Use the knowledge of wetland habitats in local areas to build a better understanding and models of wetland conditions in the Bay and their relation to the Atlantic Flyway. The USGS Black Duck research is focused on the refuges near the Bay, but is being closely correlated with similar efforts on the Flyway scale being completed by BDJV, Ducks Unlimited, and Atlantic Coast Joint Venture (ACJV). The USGS will work with partners to provide the regional understanding needed for the Chesapeake Bay. Work with partners to apply 


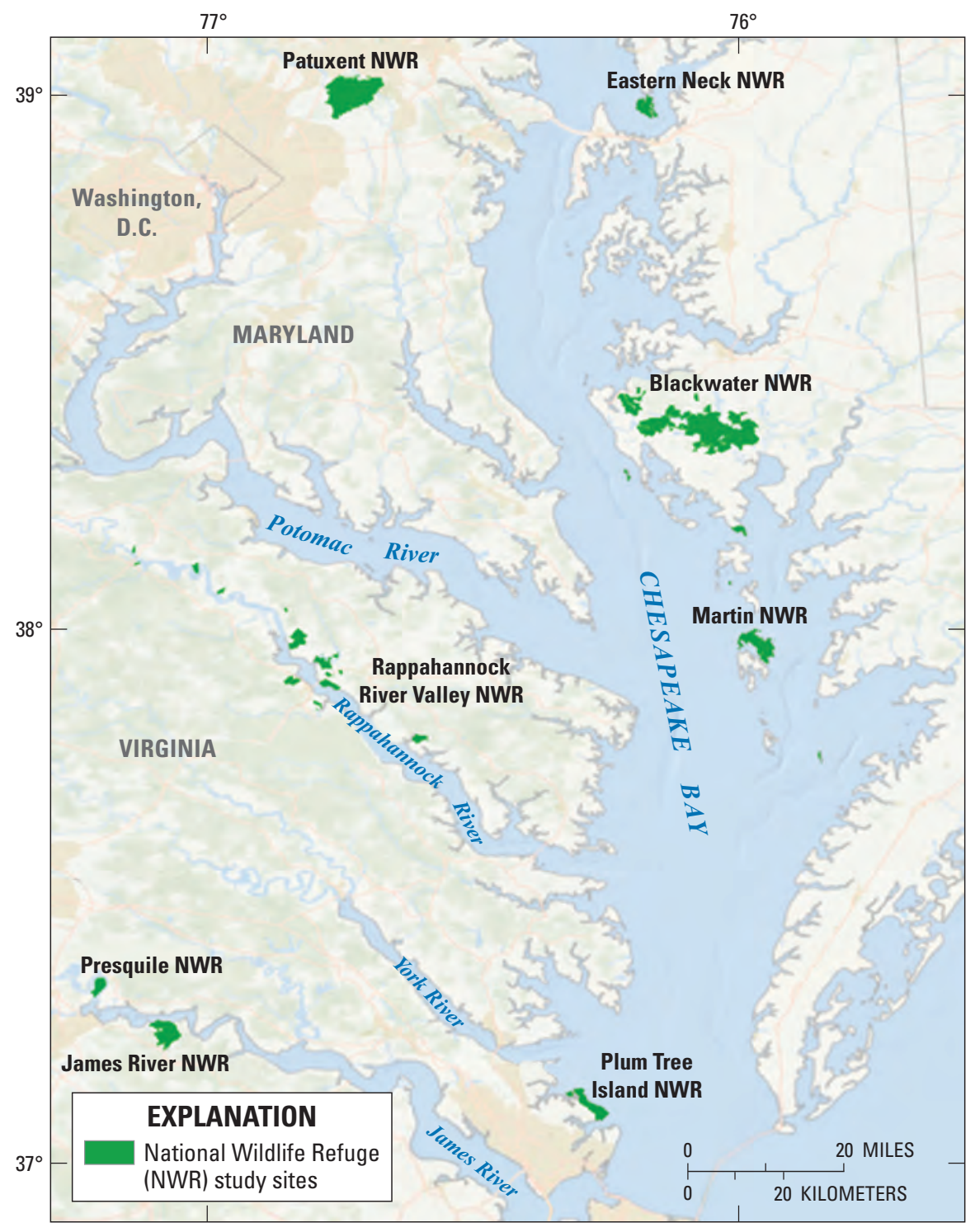

Figure 6. Current U.S. Geological Survey (USGS) study sites for Black Duck projects. Studies of Black Ducks and coastal habitats would focus on U.S. Fish \& Wildlife Service (FWS) Refuges and be expanded in the future to include additional coastal areas.

results on FWS Refuges, and landscape-scale decisions for the Bay and the Atlantic Flyway.

- Assess potential effects of sea-level rise and development on coastal habitats based on multiple supporting activities including:

- Determine the influence of sea-level rise and land-use change on potential carrying capacity of these five key habitat types for wintering Black Ducks.

- Develop a decision support tool for refuges and other key land conservation stakeholders (Ducks Unlimited) to utilize for future conservation planning to buffer management actions in the face of sea-level rise and land development pressures.

- Complete assessments of how different watersheds and shoreline types might influence an array of ecosystem functions and components to buffer for climate change and sea-level rise stressors.

- Compare the relative resource value of the different shoreline types to each of the above components. In addition, at a larger scale, correlate the diversity and 
(or) abundances of each component to overall shoreline conditions and the watershed condition.

- Explore potential efforts to complete a landscape-level assessment of island loss in the Maryland part of the Chesapeake Bay with implications for breeding waterbird resources.

- Better understand effectiveness of water-quality restoration activities for SAV and implications for waterbird populations. There are potential efforts to assess and model SAV and wetland management actions on habitat use and body condition of wintering Black Ducks.

- Enhance understanding of avian flu viruses and other pathogens on waterbird populations, filter feeders, and the environment (water and sediments). Additionally, increase our understanding of the potential risks of avian influenza viruses given the importance of the Bay to wild waterbird species and increased exposure to pathogens due to high densities of commercial poultry farms within the subwatersheds.

- Assess watershed conditions to increase our understanding of the effects of different types of shoreline hardening (from high density bulkhead to natural wetland shores) on critical Bay resources including water quality, SAV, fish, benthic macroinvertebrates, and waterbirds. This approach will provide important information for land managers to use to inform decisions related to shoreline development and preservation.

- Continue and enhance restoration research for Poplar Island to (1) provide technical advice on habitat creation or modification to enhance conditions for migratory birds, (2) monitor breeding colony development of the key waterbird species (Osprey, Least and
Common Terns, Snowy and Cattle Egrets, American Black Duck), and (3) evaluate their nesting productivity over the years.

- Assess island loss across the entire Chesapeake Bay. Islands provide important nesting and roosting habitat for wildlife species, yet assessments have been conducted historically within subsections of the Bay. Completing a baseline assessment of historical change and current status of islands within the Bay is the first step towards managing and protecting these disappearing critical habitats.

- Improve technological methods for assessing bird populations in the Bay. Although waterbird counts are conducted periodically (5 years, typically), current census methods are challenging and need to be improved. It is hypothesized that use of unmanned aerial vehicles (UAVs or drones) may provide census data that either (1) could not otherwise be completed due to physical access issues, or (2) reduces the disturbance to breeding species. Explore use of UAVs and different sensor platforms (such as high definition imagery or video, and infrared thermal-sensing cameras) to improve wildlife population estimates.

\section{Science Partners}

Studies are conducted in collaboration with a wide range of partners. A list of currently active science partners includes: FWS Chesapeake Bay refuges; Ducks Unlimited; the University of Delaware; BDJV; FWS; ACJV; Maryland Environmental Services; the U.S. Army Corps of Engineers (USACE); MD DNR; the University of Maryland (UMD), the Maryland Port Authority; Smithsonian Environmental Research Center; and NOAA. 


\section{Science Theme 2: Characterize and Explain Changes in Water Quality and Its Effect on Freshwater and Estuarine Conditions}

Water is the primary vector for moving chemical contaminants and sediments from the landscape through terrestrial, wetland, and aquatic ecosystems. Anthropogenic contaminants and sediments mobilized by human actions have been shown to alter the function of individual organisms and ecosystems as a whole. In the Chesapeake Bay and many coastal estuaries, an overabundance of nutrient and sediment has degraded waterquality conditions for fish and shellfish. EPA implemented the Chesapeake Bay TMDL in 2010, the largest restoration of its kind in the Nation, to have practices in place by 2025 to improve water-quality conditions in the Bay. This theme primarily informs Chesapeake Agreement goals for water quality (focused on the Bay TMDL), with additional benefits to help support vital habitats, and toxic contaminants goals.

- Water Quality - Reduce pollutants to achieve the water quality necessary to support the aquatic living resources of the Bay and its tributaries and protect human health.

- Toxic Contaminants-Ensure that the Bay and its rivers are free of the effects of toxic contaminants on living resources and human health.

- Vital Habitat-Restore, enhance, and protect a network of land and water habitats to support fish and wildlife, and to afford other public benefits, including water quality, recreational uses, and scenic value across the watershed.

USGS activities in this theme are subdivided into three objectives, with the first two focused on outcomes for the water-quality goal and the third providing information for vital habitats and toxic contaminant outcomes:

- 2.1 Characterize status and trends in nutrients, sediment, and streamflow.

- 2.2 Explain water-quality changes in response to human actions.

- 2.3 Collaborate to integrate hydrology and water quality with freshwater and estuarine ecosystem assessments.

Some specific information needs are to better understand stream conditions for freshwater fisheries; help inform implementation and progress of the Bay TMDL to improve conditions in the watershed for estuary shellfish and finfish; and to improve the linkage between management on the landscape - including land-use and management practicesand water-quality responses in streams and the estuary. The three objectives are designed to provide a framework to link the landscape with hydrologic conditions and ecological responses. A solid foundation of monitoring hydrologic and water-quality conditions provides the framework for developing these linkages. Linkages at the landscape level are made in two ways: (1) how does the landscape serves as a source for pollutants based on land-use and management strategies, and (2) how does the landscape affect the movement of water and associated pollutants through the ecosystem. Linkages to ecological conditions will be made based on hydrologic controls of habitat supporting fish and water-quality conditions affecting ecosystem health. Hydrologic monitoring and assessments are made in support of several cross-cutting questions, which requires collaboration and exchange with scientists from diverse disciplines - many of which are represented in science themes assessing fish and wildlife, land use, and climate change.

The cross-cutting nature of this objective addresses the function of an ecosystem from a hydrologic perspective. Thus, activities are fully supportive of goals of multiple USGS MAs. Selected MA goals being addressed by this theme include:

- Ecosystems MA: This objective addresses all five stated goals including the following: (1) improve understanding of ecosystem structure, function, and processes; (2) advance understanding of how drivers influence ecosystem change; (3) improve understanding of the services that ecosystems provide to society; (4) develop tools, technologies, and capacities to inform decision making about ecosystems; and (5) apply science to enhance strategies for management, conservation, and restoration of ecosystem.

- Water MA: Addresses the goal of predicting changes in quantity and quality of water in response to changing climate, population change, and land use. Management scenarios will be addressed.

- Environmental Health MA: Efforts to link contaminant occurrence with sources on the landscape is a critical goal being addressed.

- Climate and Land Change MA: Address the goal of characterizing land-use and land-cover change rates, causes, and consequences. 


\section{Science Theme 2 Addresses These Chesapeake Restoration Goals and Outcomes}

\section{Water-Quality Goal}

Watershed Implementation Plan (WIP) (2017 and 2025) Outcomes: USGS studies inform management approaches in the WIPs to carry out the TMDL and address four factors influencing their success: (1) understanding the factors affecting ecosystem response to load reductions, (2) improving the identification of sources, (3) examining the impact of Susquehanna River dams, and (4) enhancing the next generation of decision support tools. Studies are designed to explain observed changes in nutrients and sediment in response to management practices, which helps improve CBP water-quality models and provides feedback to develop improved WIPs. Results of these studies are being shared with the WaterQuality Goal Implementation Team, which includes all the partners working to improve water quality.

Water-Quality Standards Attainment and Monitoring Outcome: USGS is leading efforts to improve the capacity to measure progress in reducing nutrient and sediment loads to Chesapeake Bay through coordinated monitoring with EPA and the jurisdictions. USGS measures and reports on changes in stream loads annually. USGS works with scientists measuring water-quality standards attainment in the Bay to improve the understanding of ecosystem response to restoration efforts. These results provide information for milestone assessments and public accountability as feedback on the progress measured through implementation of management actions. EPA and partner jurisdictions use these results through the Water-Quality Goal Implementation Team to make adjustments to management practices.

\section{The USGS activities will also support aspects of these goals and outcomes:}

\section{Toxic Contaminant Goal}

Toxic Contaminants Research Outcome: The USGS is addressing the potential relation between nutrients, sediment, and toxic contaminants in degrading the health of fisheries.

\section{Habitat Goal}

Wetlands Outcome: USGS is involved in studies of freshwater wetlands with research on the natural water-quality functions of wetlands, and on their ability to provide water-quality benefits. This research on both natural and created and restored wetlands helps with water-quality management actions for the TMDL.

Stream Health Outcome: USGS is helping to develop metrics to measure the multiple facets of stream health. USGS is also contributing to understanding functional lift from stream restoration projects, including a literature synthesis to document the response of stream ecological conditions from restoration projects and enhanced monitoring.

SAV: USGS is participating in technical synthesis of SAV and application of selected results to restore and conserve SAV. 


\section{Objective 2.1 Characterize Status and Trends in Nutrients, Sediment, and Streamflow}

\section{Science Needs and Questions}

Through this objective, USGS will address the science need for monitoring, assessment, and reporting of hydrologic and water-quality conditions throughout the Chesapeake Bay watershed to discern the effectiveness of restoration actions being implemented for the Bay TMDL and other restoration activities of the Chesapeake Agreement. In addition, this objective meets DOI priorities to (1) build a landscape-level understanding of our resources, and (2) assure healthy watersheds and sustainable, secure water supplies.

The USGS is the recognized leader in monitoring hydrologic and water-quality conditions across the Chesapeake Bay watershed. The CBP has a nontidal water-quality monitoring network through a coalition of partners including USGS, EPA, states, the District of Columbia, and River Basin Commissions. Nearly $\$ 300$ million of Federal funds, and additional State and local Government funds are being spent annually to improve water quality in the Bay and its watershed. The CBP nontidal water-quality monitoring network, along with the tidal waters network, are designed to provide information on water-quality improvements as management actions are implemented for the TMDL. Given the importance of the nontidal network and the dramatic advancements in monitoring technology and reporting processes, it is critical that the USGS continues to guide and shape the water-quality monitoring and reporting over the coming decades. Activities in this objective focus on the measurement, statistical analysis, and communication of water-quality and hydrologic changes across the Chesapeake Bay watershed.

A principal application of the results of monitoring is in support of the Chesapeake Agreement water-quality goal's attainment and monitoring outcome-

"Continually improve the capacity to monitor and assess the effects of management actions being undertaken to implement the Bay TMDL and improve water quality. Use the monitoring results to report annually to the public on progress made in attaining established Bay water quality standards and trends in reducing nutrients and sediment in the watershed."

Results from the monitoring program will be used to support the CBP 2017 Midpoint Assessment of the TMDL as well as assessments needed through 2025. Thus, the principal cross-cutting question to be addressed is: How is the water quality of rivers and estuaries responding to restoration actions, and changing land use?

The following supporting questions outline the information needs that will guide monitoring priorities necessary to meet specific management information needs of the TMDL and Chesapeake Agreement:
- To what extent are nutrient and suspended-sediment concentrations and loads changing in major tributaries to Chesapeake Bay?

- How can we better monitor and explain changes in nutrient and suspended-sediment transport in urban and agricultural watersheds undergoing restoration activities?

- How can innovative trend-assessment techniques provide insight into the nature of long-term and recent changes in conditions in relation to watershed changes?

- To what extent can the use of state-of-the-art continuous monitoring techniques significantly improve the manner in which environmental change is measured and can this improve the assessment of water-quality and ecological responses in the estuary?

- To what extent are streamflow conditions, such as frequency and magnitude of floods and droughts, changing across the watershed?

- What are the interactions between developmental pressures, geomorphic patterns, and sediment transport on the availability of habitat for fisheries?

\section{Anticipated USGS Activities}

USGS activities to characterize status and trends in nutrients, sediment, and streamflow encompass a range of monitoring, data analysis, and reporting activities. Each of these activities is closely tied to core USGS programs as well as a diverse group of local partners. The following list of activities outline USGS roles in monitoring in support of Chesapeake Bay and watershed restoration efforts.

- Lead the operation, maintenance, and enhancements to the Chesapeake Bay watershed monitoring network (over 120 stations). This network operated by a partnership consisting of the EPA, USGS, states, and Basin Commissions is the backbone monitoring supporting the water-quality standards attainment and monitoring outcome for nontidal waters. There are an additional 300 streamgages, funded by a variety of local, State, and Federal partners, used to address a wide variety of water-resources issues.

- Communicate current status and changes in waterquality conditions based on the nontidal network to the Bay communities through annual updates, Web pages, and technical reports highlighting new methods and findings. Key publications will be prepared in support of the 2017 Midpoint Assessment and annual evaluations of the TMDL through 2025. 
- Analyze monitoring results to determine the status and changes in loads and concentrations of pollutants utilizing the newest technologies such as Weighted Regressions on Time, Discharge, and Season (WRTDS) to determine the extent to which restoration actions and land-use changes are having an effect on water quality in streams.

- Integrate reporting of changes in stream loads for major tributaries into Chesapeake Bay tidal conditions change reporting. This integrative process will support a more seamless presentation of annual assessments in support of the water-quality standards attainment and monitoring outcome.

- Strategically enhance the monitoring techniques for the network by introducing new technologies and techniques into the field as appropriate. Initial efforts include using continuous surrogate and direct measurement sensors such as temperature, conductance, turbidity, $\mathrm{pH}$, dissolved oxygen, and nitrate to improve trend and flux estimates. These techniques will be applied at small and large rivers to support assessing changes because of land management at the small scale and to refine linkages with estuarine waters at major tributaries to the Bay.

- Explore opportunities to establishing a network of sites to determine the interactions between developmental pressures, geomorphic patterns, and sediment transport on the availability of habitat for fisheries.

The USGS and Chesapeake Bay Partnership waterquality monitoring networks extend across the Chesapeake Bay watershed (fig. 7). The CBP nontidal network includes 120 streamflow gages and sampling sites operated by USGS, states, and River Basin Commissions. An integral part of the CBP network are the nine River-Input monitoring stations, which measure nutrient and suspended-sediment flux to tidal waters of the Bay from over 75 percent of the watershed. Additionally, smaller watersheds have spatially and temporally intensive monitoring to assess changes over time and effects of management actions in agricultural and urban settings.

\section{Science Partners}

Hydrologic and water-quality monitoring in the Chesapeake Bay watershed rely on an extensive degree of collaboration with State and local partners. Partners supporting the water-quality and streamflow networks include Federal agencies (USGS, EPA, USACE, and the National Weather Service); State agencies in Delaware, Maryland, New York, Pennsylvania, Virginia, and West Virginia, and the District of Columbia; and Counties and local governments. Monitoring partners in small watersheds include the EPA; U.S. Department of Agriculture, National Resources Conservation Service (USDA NRCS); Soil and Water Conservation
Districts; Fairfax, Rockingham, and Shenandoah Counties, Va.; Kent, Queen Anne's, and Montgomery Counties, Md.; and Dauphin, Lebanon, and Lancaster Counties, Pa.

\section{Objective 2.2 Explain Water-Quality Changes in Response to Human Actions}

\section{Science Needs and Questions}

The previous objective provides the monitoring needed to document water-quality and hydrologic change, whereas this objective meets the need to explain water-quality change. Quantifying linkages between human activities, landscape change, water-quality changes, and ecosystem response remains a challenge. This objective focuses on bridging the science of measuring landscape change with hydrologic, geomorphic, and water-quality disciplines. In doing so, this objective meets the needs of the CBP water-quality goal and DOI efforts to restore conditions for fish and wildlife.

To date, observed changes in tributary water quality and the estuary do not meet the expected improvements from three decades of voluntary CBP efforts to reduce nutrients and sediment. The lack of significant improvements was the primary reason for EPA to issue the Chesapeake TMDL in 2010 that requires a regulatory framework for water-quality improvements. The USGS is bringing its expertise for monitoring and hydrologic studies to explain the observed changes in water quality in context with historical and ongoing management actions and the associated influence of watershed properties and land change. Many currently planned activities will support of the 2017 Midpoint Assessment of the TMDL. Longterm analysis of landscape change and aquatic ecosystem response will continue through the period of TMDL implementation (2025).

The cross-cutting question being addressed is: "How is the water quality of rivers and estuaries responding to restoration actions, and changing land use?"

The associated supporting science questions are:

- How do landscape characteristics such as land use, soils, slope, geology, aquifer characteristics, wetlands, and flood plains affect fundamental hydrologic transport properties, and what is their role in governing nutrient and sediment delivery to streams?

- Which landscape characteristics and changes have the most influence on observed changes in stream condition and nutrient and sediment loads and can we improve the characterization of pollution contribution from major source sectors for nitrogen, phosphorus, and sediment? 


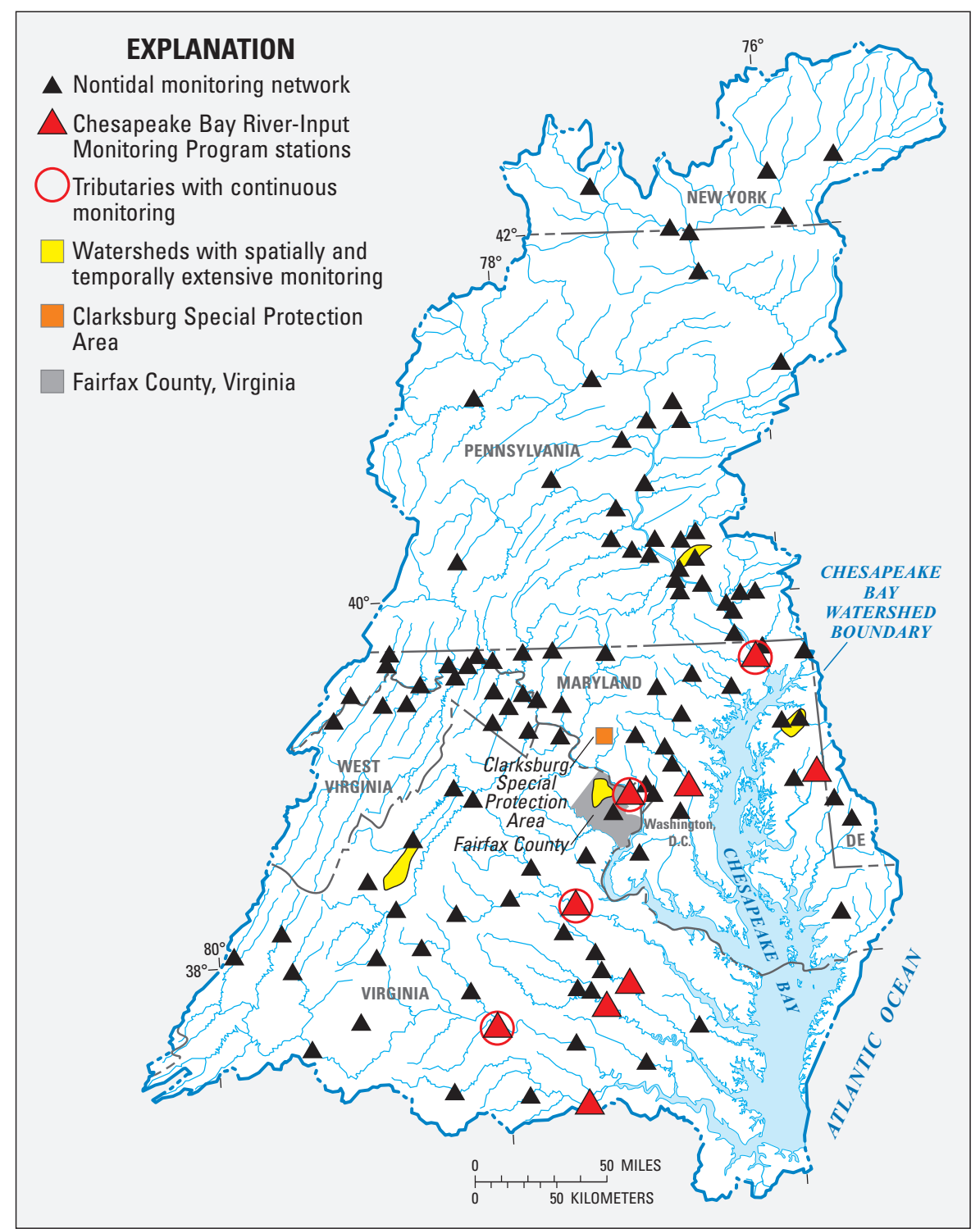

Figure 7. Location of selected waterquality networks. Some of the key networks led by the U.S. Geological Survey (USGS) include (1) Chesapeake Bay Program (CBP) nontidal monitoring network stations, (2) Chesapeake Bay River-Input Monitoring Program (RIM) stations, (3) RIM stations with continuous monitoring, (4) watersheds with spatially and temporally extensive monitoring, (5) Clarksburg Special Protection Area, and (6) Fairfax County, Virginia Best Management Practices (BMPs) study area.
- Are measured changes in nutrient and suspendedsediment fluxes in streams matching expected levels of load reductions based on implemented restoration actions?

- To what extent can decreases in nitrogen from atmospheric deposition explain improvements in nitrogen concentrations and loads in streams?

- What is the role of groundwater as a transport process for nutrient delivery to streams, and to what extent do lag times delay responses to management practices?

- To what extent do lengthy sediment transit times from the landscape to the estuary delay the effect of sediment management strategies?
- How does what we know about nutrient and sediment transport improve our understanding of the occurrence of EDCs and other toxic compounds in the aquatic environments?

- How do environmental and management factors, such as changes in impervious surfaces, alter the physical hydrology and sediment transport of streams?

- What is the effect of the Conowingo Reservoir on the magnitude and timing of nitrogen, phosphorus, and sediment loads to Chesapeake Bay as it reaches dynamic equilibrium with respect to sediment storage capacity? 


\section{Anticipated USGS Activities}

The fulfillment of science needs for this objective requires a cross-cutting approach involving new field studies as well as analysis of long-term monitoring data (fig. 8). Hydrologic analyses are being made in conjunction with land-use and land-management data compiled by the USGS and other CBP partners. Anticipated activities include the following:

- Enhance field studies including intensive watershed studies and regional studies to characterize how the landscape and its changes influence nutrient and sediment sources, transport processes, and fate.

- Characterize the changes in land-use and land-management activities throughout the watersheds and their expected impacts on nutrient and sediment loading relative to stream-water quality monitoring locations. USGS and USDA have entered into a data sharing agreement that provides limited access to high-resolution agricultural BMP data for science purposes. The USGS plays a critical role in accessing and summarizing USDA farm service agency records on implementation for the partnership and these summarized data are combined with State records to form an improved database of reported agricultural best management practices (BMPs) implementation.

- Initiate topical studies based on nontidal network monitoring results to explain observed changes in water quality in relation to BMPs and other management actions and land-use changes. The USGS will continue

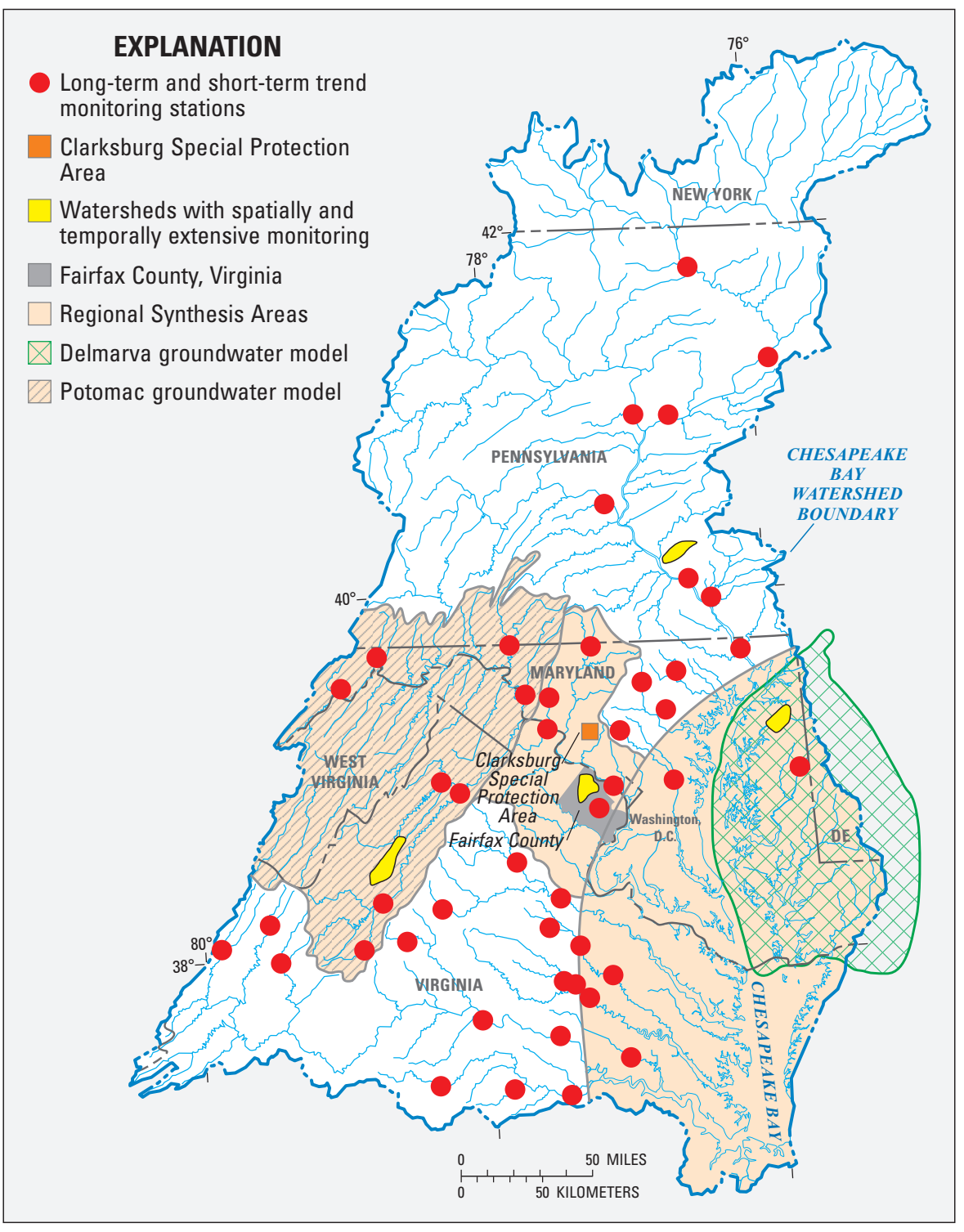

Figure 8. Location of U.S. Geological Survey (USGS) groundwater modeling areas, long-term and short-term trend monitoring stations, regional synthesis areas, and small watershed study areas. 
single-basin and multi-watershed approaches to compare observed and expected changes in water quality, and identify the most likely drivers for observed improvements or lack of improvement.

- Enhance statistical analysis of historical monitoring data and models (including CBP WSM5.3.2, SPARROW, and groundwater models) to determine the relative contribution of individual landscape and source variables on observed changes in stream condition.

- Quantify the role of groundwater in transporting surface-derived nitrogen to streams, including developing the following:

- Groundwater-flow models and MODPATH simulations to describe the expected effects of groundwater residence time on the timing of responses to management actions in streams.

- New regionalizing techniques to assess the role of groundwater on the timing and magnitude of nitrogen delivery to streams.

- Field studies of nitrogen in shallow groundwater and its response to changing agricultural management actions.

- Spatial and time variable statistical models (SPARROW) to link changes in land use and management actions to observed loads in parts of the Chesapeake watershed. Models will explicitly include groundwater lag and storage terms to more accurately represent long-term hydrologic processes.

- Integrate field studies and models to identify sediment sources; quantify the timescales of sediment erosion, storage, and transport; and focus on the relation between response times and management actions.

- Evaluate how hydrology and water-quality change in response to urban and suburban stormwater BMP strategies.

- Characterize impacts of urban development on streamflow and its implication for water quality and sediment transport, including the following: (1) development of techniques to map channel and landform features in flood plains relevant to sediment erosion, transport, and deposition processes; and (2) analysis of impervious surface connectivity and other features of urban development on streamflow and water quality.

- Further understand the changes in nutrient and sediment transport characteristics of the Lower Susquehanna River reservoir system.

\section{Science Partners}

Explaining changes in response to human actions utilizes approaches at a variety of scales and the support of partner monitoring and management agencies. USGS has developed a partnership with the EPA Chesapeake Bay Program office to share modeling and data tools to explain changes in nutrient and sediment loads. In addition, USGS has engaged a large collaborative audience through the CBP water-quality goal team, which includes six states (Delaware, Maryland, New York, Pennsylvania, Virginia, and West Virginia), the District of Columbia, as well as all counties and local jurisdictions. Each of these partners is responsible for enacting pollution controls to reduce loadings to the Chesapeake Bay. As such, all are interested partners and audiences of explanations of recent and historical changes in stream quality.

Partners for small watershed studies, include the USDA NRCS; Soil and Water Conservation Districts; Fairfax, Rockingham, and Shenandoah Counties, Va.; Kent, Queen Anne's, and Montgomery Counties, Md.; and Dauphin, Lebanon, and Lancaster Counties, Pa.

Additional topical partners include The Nature Conservancy, Exelon Power Company, the University of Maryland Center for Environmental Science (UMCES), the Maryland Soybean Board, the Maryland Grain Producers Utilization Board, James Madison University, George Mason University, and Virginia Polytechnic Institute and State University.

\section{Objective 2.3 Collaborate to Integrate Hydrology and Water Quality with Freshwater and Estuarine Ecosystem Assessments}

\section{Science Needs and Questions}

Large parts of the aquatic communities in the Chesapeake Bay watershed are known to be impaired based on State and EPA assessments. The Chesapeake Bay is impaired due to nutrient enrichment, excessive sediment, and toxic contaminants. Many miles of streams are also impaired due to excessive nutrients, bacteria, contaminants, sediment, and associated habitat impairment. The effects on the health and population of fish communities include the following: mortality, intersex conditions, and human consumption advisories. The objective helps provide an improved understanding of the linkage between the hydrologic conditions, water quality, and habitat to the effects on ecosystems (primarily fisheries).

This objective builds upon the results of improved monitoring (objective 2.1) and explanation of change (objective 2.2) and applies this information to support explanation of ecosystem responses in the watershed and tidal waters of Chesapeake Bay. Within this objective, USGS scientists play an important contributory role by providing freshwater 
fisheries and estuarine scientists with a hydrologic perspective on the sources and movement of chemical contaminants though the ecosystem. The information will benefit information needs of CBP and DOI partners who are addressing the following outcomes in the Chesapeake Agreement: waterquality monitoring and assessment; fish habitat, Brook Trout, streams, SAV, and toxic contaminants research.

The efforts will address three cross-cutting questions:

- How is the water quality of rivers and estuaries responding to restoration actions, and changing land use?

- How do land and climate change affect fish communities, fish health, and freshwater habitats?

- What are the relationships among land use, water quality, contaminants, and the health of fish and wildlife?

More specific supporting questions that contribute to cross-cutting work include:

- What is the occurrence of EDCs and other toxic compounds in water and sediment, and how does their occurrence relate to land uses and contaminant sources such as WWTPs, animal-feeding operations and other sources?

- What are the mechanisms and pathways for exposure of fish, fish eggs, and young to EDCs and other toxic compounds in water and sediment?

- How do differences in water quality and habitat impact the health of Brook Trout and other freshwater fish?

- How are changes in tributary loads resulting in changes in estuarine conditions, ecosystem health, and attainment of water-quality standards?

- What controls individual embayment (James River estuary and Potomac River estuary, for example) responses to upstream changes in nontidal water-quality inputs?

\section{Anticipated USGS Activities}

Activities in this objective are shown as a supporting role for integrated research ongoing within the USGS or partner agencies and universities. USGS staff will bring their unique hydrologic and water-quality perspective on the critical questions to develop assessments and reports.

- Collaborate with tidal researchers to develop an approach to better integrate nontidal fluxes and hydrology into the ongoing assessment of water-quality conditions in the receiving waters of the estuary. CBP and the USGS have initiated a coordinated effort to explain water-quality and ecological changes in the estuary. Development of trend detection and normalization processes for estuarine waters is similar to those used by USGS for nontidal waters. CBP partners will benefit from USGS participation.

- Conduct field-scale monitoring of sediment, water quality, and organism health in nontidal waters to understand how the occurrence and transport of toxic contaminants and EDCs are affected by exposure and uptake pathways, and affect freshwater fisheries. We will bring research-level field laboratories to existing long-term monitoring stations to build upon a base level of knowledge at each site. Mobile fish-effects laboratories will be used in key locations to focus on specific sources of pollution including WWTPs, confined animal feeding operations, and row crop agriculture. Additional sampling of water and sediments may be used to assess contaminant pathways such as arsenic on sediments.

- Support studies of the role of nutrient and sediment, hydrology, and water temperature on the health of aquatic organisms, especially Brook Trout and other freshwater fish. USGS water-quality scientists will collaborate with fisheries researchers to develop an approach to use knowledge of drivers of nutrients, sediment, temperature, and streamflow into regional assessments of fish health and Brook Trout. Promising topics include assessments of temperature and streamflow effects on Brook Trout, which may be assessed through field investigations or statistical modeling using SPARROW.

- Enhance studies of changes in sediment and nutrient transport in the Susquehanna River Reservoir system and changes in the Chesapeake Bay's water-quality and ecological response. UMCES has initiated a study of potential effects of the changing sediment and phosphorus loads from Conowingo Dam. This study is designed in collaboration with USGS's study of changing sediment-loading characteristics.

- Additional field and statistical studies of the effect of geomorphology and sediment on the health of aquatic and wetland ecosystems. Determine if sediment is affecting gill activity and getting into fish dermal tissue. Continue to integrate sediment/geomorphic assessments done in conjunction with ecological assessments conducted by Chesapeake and National Water-Quality Assessment (NAWQA) regional ecological and fisheries studies.

- Explore opportunities to assess the link between nutrients and sediment (based on the nontidal network results, SPARROW models, and geomorphology studies) with benthic macroinvertebrate conditions. 
- Explore opportunities to link flood-plain function with ecological health of riparian ecosystems.

There are several geographic areas for this objective (fig. 9). These areas are determined based on existing studies and cooperative opportunities. The geographic focus on EDC and toxic compound studies will focus on the Susquehanna and Potomac River watersheds. Trout habitat efforts will be coordinated in the suitable headwaters streams across the watershed. Susquehanna Reservoir studies will focus on the lower main stem Susquehanna, and ecological responses in the upper Bay and main channel.

\section{Science Partners}

Capitalizing on collaborative opportunities is essential for successfully linking disciplines that may traditionally have little programmatic interaction. USGS is working through the CBP Scientific Technical Assessment and Reporting (STAR) workgroup to develop collaborative projects to link estuarine responses with changes in tributary loads and water quality. In addition, the USGS and UMCES are co-chairing a workgroup to bring a diverse group of researchers together to explain drivers of change in the watershed and the Bay. Within the watershed, collaborative partners include: EPA CBP, the State of Maryland, UMCES, FWS, State fisheries agencies, and EBTJV.

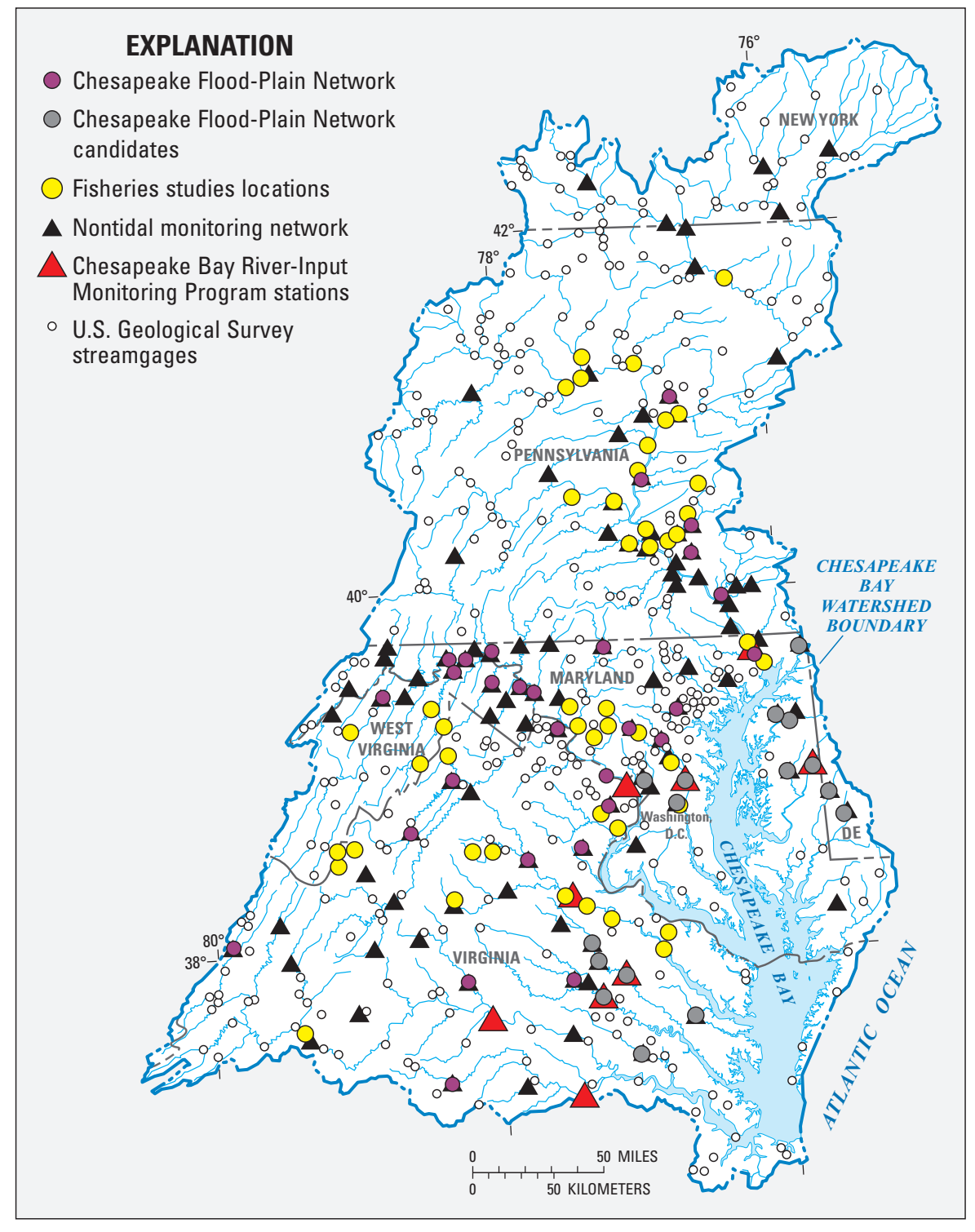

Figure 9. U.S. Geological Survey (USGS) streamflow-gaging network, nontidal network stations, and their intersection with Fisheries studies locations. 


\section{Science Theme 3: Assess and Forecast Effects of Climate and Land Change on Ecosystem Conditions}

The two major drivers of ecosystem change in the Chesapeake and other areas of the Nation are: (1) land change associated with increases in population; and (2) climate change including sea-level rise, temperature, and hydrologic variability. Many of the current and historical land-use practices have been shown to have a significant negative impact on water-quality and biological resources in the Bay and throughout the watershed. The Chesapeake Agreement recognized the importance of land and climate change by including goals on climate resiliency and conserving lands. Improved information on land and climate change is critical to meeting the several other goals in the Chesapeake Agreement: (1) sustaining fisheries, (2) vital habitats, (3) water quality, and (4) healthy watersheds. Based on the interaction between land and climate change, the USGS is addressing their effects on ecosystem conditions under a single science theme, with three objectives:

- 3.1 Assess the combined effects of climate and land change on streams and fisheries.

- 3.2 Assess the effects of sea-level rise and land development on wetlands and ecosystem conditions and their resiliency.

- 3.3 Characterize and forecast land change and provide implications for conservation.

This science theme directly supports USGS efforts to provide science to support the conservation and restoration of fish, wildlife, and habitat (Theme 1) and helps to explain water-quality change (Theme 2). The efforts will directly support FWS and NPS needs to make lands and habitats more resilient to climate and land change. The USGS efforts will also be done in collaboration with many partners that are working to carry out the Priority Agenda for Enhancing the Climate Resilience of America's Natural Resources (Council on Climate Preparedness and Resilience, 2014).

Understanding the combined effects of climate and land change are fundamental priorities of the USGS Climate and Land Change MA and also have a close interaction with the Ecosystems, Water, and Core Science Systems MAs. Some of the MA goals being addressed include:

- Climate and Land Use-MA goal related to land-use and land-cover change rates, causes, and consequences. The USGS has a long history of providing land-use and land-cover data through its Landsat imagery archive National Land Cover Databases.

- Ecosystems-Understand drivers that influence ecosystem change.
- Water-Forecasting changes in water quantity and quality in response to changing climate, population, land use, and management scenarios.

- Core Science Systems - Conduct analysis and synthesis to improve coverage, quality, usability, and timeliness of information.

- Hazards - Fundamental understanding of hazards and impacts.

\section{Objective 3.1 Assess the Combined Effects of Climate and Land Change on Streams and Fisheries}

\section{Science Needs and Questions}

Stream ecosystems and aquatic biota can be affected when water temperatures and flows exceed critical thresholds. Rising water temperature and changes in streamflow that can result from climate or land change have been demonstrated to impact sensitive species. Changing hydrologic and temperature conditions will affect the transport of nutrients, sediment, and contaminants in the watershed and the conditions in tidal waters. The combined effects of climate and land change on water quality, habitat, and fisheries in the watersheds are needed to assist resource managers with informed decision making.

Meeting the goals of the Chesapeake Agreement will require science about the combined effects of land and climate change on achieving goals for fisheries, habitat, water quality, healthy watersheds, and land conservation. Specific agreement outcomes to address the science needs include (1) monitoring and assessment outcome under climate resiliency, and (2) land-use methods and metrics development outcome under land conservation. Minimizing the vulnerability of fish, wildlife, and lands to the adverse impact of climate and land change addresses DOI priorities. Specific DOI priorities being addressed include (1) provide a landscape-level understanding for resource management, and (2) achieve healthy watersheds and secure water resources.

The following science questions will be addressed to help meet the science needs. The cross-cutting question: "How do land and climate change affect freshwater fish communities, health, and habitats?"

The supporting science questions are:

- How is stream temperature changing across the watershed as the result of climate and land change?

- How are changes in precipitation patterns affecting streamflow (timing and magnitude)? 


\section{Science Theme 3 Addresses These Chesapeake Restoration Goals and Outcomes}

\section{Climate Resiliency Goal}

Climate Monitoring and Assessment: The USGS is providing leadership for partners to collaborate on the Monitoring and Assessment Outcome and conducting studies to address the potential effects of climate and land change for three primary topics: (1) freshwater fisheries and streams, (2) coastal habitat supporting waterfowl, and (3) DOI lands and resources. USGS studies are assessing stream and temperature effects on fisheries and sea-level rise impacts on coastal habitat and DOI lands. These studies, and other partner efforts through the CBP climate workgroup, will be used by the CBP Goal Teams to consider potential effects of climate change on conservation and restoration activities.

\section{Habitat Goal}

Wetlands Outcome: USGS coastal wetlands efforts include (1) monitoring relative sea-level rise near Blackwater National Wildlife Refuge and other coastal wetlands, (2) assessing long-term changes in wetlands and the effects of storm surge, and (3) modeling marsh migration due to sea-level rise and land-use change. Information from coastal wetland studies will help inform FWS and states working to restore coastal wetlands. The USGS will use the Chesapeake Land Change Model to predict areas where development, along with climate change, may cause loss of wetlands. The findings will be used by DOI land managers (FWS, NPS, and BLM) to consider threats from climate and land change as they plan and implement wetland restoration activities.

\section{Land Conservation Goal}

Land-Use Methods and Metrics Development Outcome: The USGS will lead the effort, through collaboration with CBP partners, for monitoring land change that can be used to help assess the impacts of land conversion on water quality, healthy watersheds, and communities. The USGS will contribute high-resolution, land-cover and elevation data that complements data being collected by Federal, State, and local entities across the watershed. USGS will develop the methodology for assessing landscape change and work through the CBP land cover workgroup to finalize the method by 2016. USGS will coordinate subsequent updates of land cover every 2-5 years and develop approaches to quantify the impacts of land conservation. The results will support the Healthy Watersheds Goal Team and improve the framework for models used for water-quality restoration and land protection.

\section{Healthy Watersheds Goal}

Healthy Watersheds Outcome: The USGS is coordinating efforts to carry out the CBP outcome to sustain " 100 percent of the state-identified currently healthy watersheds." The USGS is working with states to understand the threats to healthy watersheds. USGS will use the Chesapeake Land Change Model to forecast areas where development will increase so states can assess the vulnerability of healthy watersheds and develop strategies to continue their protection. USGS forecasts of land development will also inform the CBP land protection outcome and identify areas being considered for protection that may be vulnerable to land and climate change.

\section{The USGS activities will also contribute to these outcomes:}

2017 WIP: USGS is leading development of new land cover for the CBP watershed model.

Monitoring and Attainment: Using land-cover and land-use change to explain water-quality trends.

Riparian Forest Buffers: Tracking change in buffers through enhanced land-cover monitoring.

Land Protection: USGS forecasts of land development will also inform the CBP land protection outcome. 
- How will changes in impervious surfaces affect streamflow?

- What are the implications of changes in stream conditions on sensitive fish species in the watershed (e.g., Brook Trout and migratory species)?

- How are nutrient and sediment loads, and effectiveness of water-quality practices, going to be most affected by changes in the magnitude and frequency of storm events?

\section{Anticipated USGS Activities}

Activities in this objective will provide information on temperature and hydrologic change based on climate variability and change in land characteristics to help address potential effects on freshwater fish populations and streams in the Bay watershed and include:

- Collaborate with ongoing studies of freshwater fisheries (Objective 1.1) to assess the effects of land and climate on Brook Trout. The studies would be conducted mostly in localized areas, such as Shenandoah National Park (fig. 4). Additional regional information will be generated to support development of forecasting models based on studies of Brook Trout to broader areas. The regional analyses would include producing estimates of: (1) regional changes in streamflow including based and flood recurrence; (2) regional changes in stream temperature; (3) historical land use and land practices; and predictions of potential future development and impervious surfaces. This regional information will be used in models to help identify the Brook Trout habitats that are vulnerable to climate and land change.

- Assess the effects of climate and land-use change on other freshwater fish species. In collaboration with the Northeast and Appalachian Landscape Conservation cooperatives and the Northeast Climate Science Center, the potential effects of alternative future scenarios will be related to thresholds for flow and temperature for representative aquatic biota. Past changes in stream temperature and flow in streams will be also assessed, and will aid in forecasting future change. The information will help inform adaptation strategies for biota and their habitat. Changes in streamflow and temperature will also be critical to help partners assess the combined effect of climate and land-use change scenarios on the delivery of water, nutrients, and sediment to the Chesapeake Bay.

- Evaluate existing information on stream temperature, precipitation patterns, and streamflow to improve long-term monitoring of climate change. The USGS will work with partners to identify where insufficient data exists and monitoring needs to be improved. Partners will collaborate on opportunities to enhance existing monitoring networks with collection of additional parameters needed to assess changing climatic conditions.

\section{Science Partners}

Studies are conducted in collaboration with a wide range of Federal, State and university partners. A list of currently active science partners includes: FWS, NPS, NECSC, Northeast and Appalachian LCCs, and the EBTJV. All of these activities will require coordination through a new CBP working group on climate change.

\section{Objective 3.2 Assess the Effects of Sea-Level Rise and Land Development on Wetlands and Ecosystem Conditions and their Resiliency}

\section{Science Needs and Questions}

Sea-level rise and development have adverse effects on coastal areas and associated DOI lands. Wetlands are the critical habitat threatened by sea-level rise, and they provide important services for waterbirds and water quality. Information on the resiliency of wetlands is important for long-range planning and habitat adaptation strategies. Assessment of regional factors such as subsidence and glacial rebound is needed to better understand projections of relative sea-level rise in the Chesapeake Bay. Sea-level rise projections, and the hazards of coastal flooding and extreme events, are critical to planning efforts for both natural resources and infrastructure to be more resilient to climate change. This is especially applicable to DOI lands and parks along the Chesapeake Bay and tidal rivers.

This objective is focused on addressing the interconnection between several outcomes in the Chesapeake Agreement including: monitoring and assessing climate change and the effects on wetland and Black Ducks. The information will help inform development of adaptation strategies for these outcomes. The CBP climate adaptation outcome will also attempt to build from restoration efforts related to Hurricane Sandy restoration. In 2012, a storm surge from Hurricane Sandy destroyed coastal communities and ecosystems along the Mid-Atlantic coast. As a result, there is an increased need for an understanding of how to maintain or enhance the resiliency of coastal regions. The USGS is enhancing science to support ecological resiliency as part of the DOI's Hurricane Sandy Restoration effort. We will build on these activities to address CBP needs, to enhance climate resiliency of DOI lands and parks, and habitats important to fish and wildlife. 
The science questions to address the needs include the cross-cutting question: "How are coastal wetlands and their carrying capacity for waterbirds affected by changing sea level and land use?"

The supporting questions include:

- What are the projected rates and levels of sea-level rise in the Bay?

- Which of the several sea-level rise models for the MidAtlantic should be used?

- What are the projected effects on near-shore wetlands?

- How will land change affect the ability of wetlands to retreat in response to sea-level rise?

- How do wetlands help to reduce tidal surge and coastal erosion as the result of major storm events?

- How is wetlands loss and resiliency affected by major storm events?

\section{Anticipated USGS Activities}

Activities will focus on addressing the combined effects of climate and land change on coastal wetlands and DOI lands. The activities will be done in collaboration with investigators addressing wetlands and their carrying capacity to support Black Duck populations (Objective 1.3 of this plan). Activities providing unique information on sea-level rise and wetlands responses at varying time frames include the following:

- Enhance monitoring and modeling of marsh migration in response to sea-level rise. Studies of relative sea-level rise and marsh migration will be expanded. The enhanced studies will focus on the FWS Refuges where the USGS is studying wetlands to support the carrying capacity of Black Ducks (Objective 1.3). The USGS will assess the feasibility to construct more regional models of the effects on wetlands.

- Document long-term changes in marsh response to sea-level rise based on marsh sea-level reconstructions from sediment cores taken from threatened Bay region tidal marshes. The cores and associated paleoecology provide insights into the rates of relative sea-level rise, extreme storms, nutrient and sediment influx, factors influencing subsidence, and climate variability.

- Use results of Atlantic Coast studies to provide implications of long-term rates of sea-level rise due to the combined effects of subsidence, glacial rebound, and climate change on the Chesapeake Ecosystem.

- Identify areas where development pressures may most affect wetlands will be made based on the refined USGS land-change model (described in the next objective). This will be used to help identify areas where the ability of some marshes to retreat inland may be limited.

- Assess wetlands loss and resiliency in connection with major storm events based on Hurricane Sandy studies with the purpose of understanding the effect of wetlands in mitigating the impact of storm surge on shorelines during large events. This information will also be utilized to develop storm surge models that predict inundation during those events. Newly installed tidal gages and sensors deployed during storms will provide additional data on inundation and trends in sea level over time. This increase in the number of tide stations across the Bay will aid in understanding spatial differences in sea-level rise that occur across the Chesapeake Bay. The USGS will work with partners to identify other monitoring to be enhanced to address the effects of sea-level rise on wetlands.

- Incorporate results of the new analysis of effects of sea-level rise and development on wetlands into decision support tools to support several partner efforts: (1) informing strategies for wetland restoration, conservation, and resilience; (2) providing implications for the carrying capacity of wetlands to support Black Duck populations; (3) adaptation strategies for DOI lands (NPS parks, FWS Refuges, and BLM lands) near the Bay.

Assessment of sea-level rise and its impact on wetlands loss and subsequent impact on Black Duck habitat will initially focus on the Blackwater National Wildlife Refuge area (fig. 10).

\section{Science Partners}

Studies are conducted in collaboration with a wide range of Federal, State and university partners including: NOAA, USACE, FWS, NPS, NECSC, Northeast and Appalachian LCCs, BDJV, and the Federal Emergency Management Agency.

\section{Objective 3.3 Characterize and Forecast Land Change and Provide Implications for Conservation}

\section{Science Needs and Questions}

Land-use change, particularly urban development, is one of the major factors affecting the health of the Chesapeake Bay and ecosystems across the Nation. Development pressures pose a significant threat to conservation of vital lands and watersheds, and can potentially counteract the benefits of 


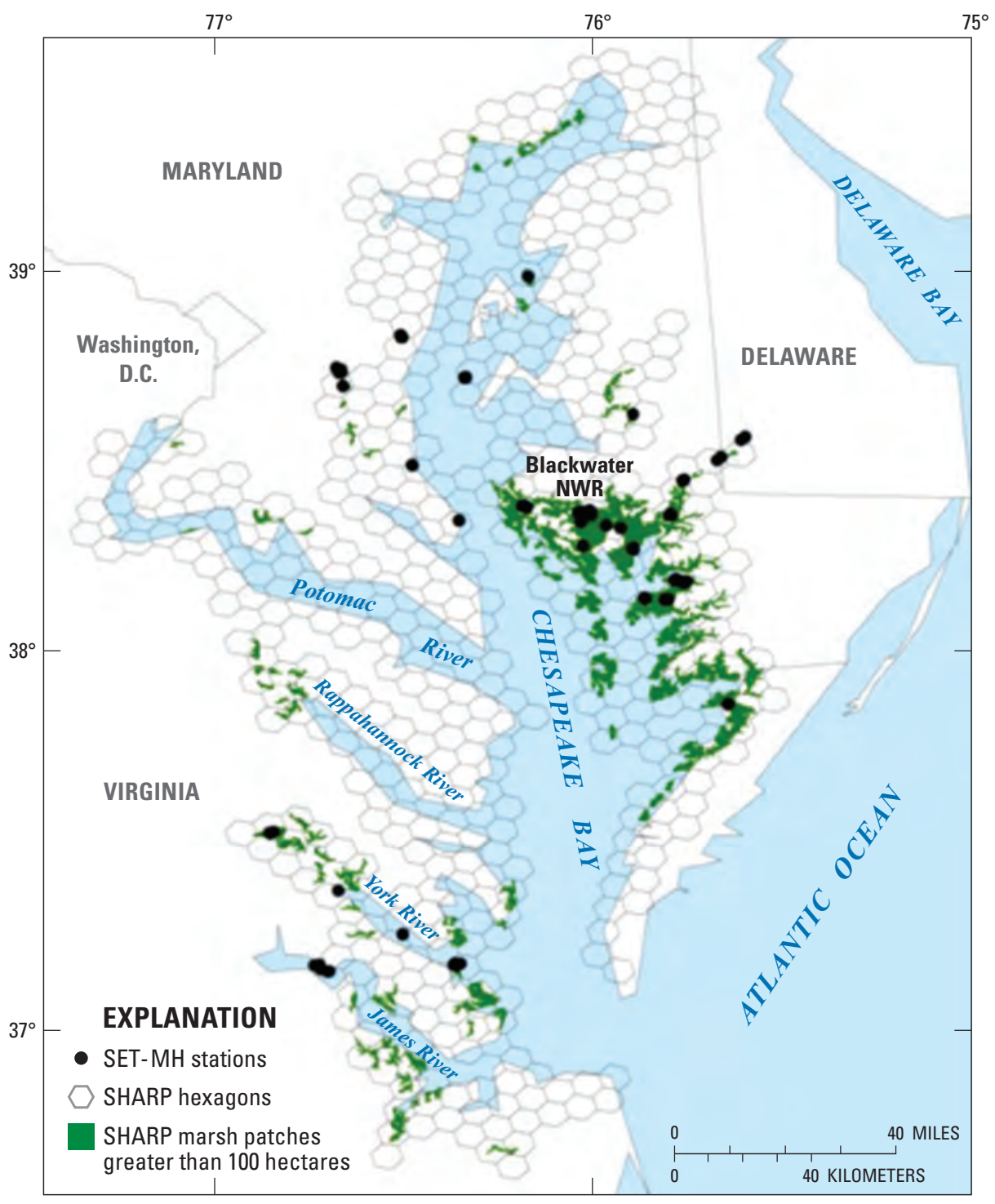

Figure 10. U.S. Geological Survey (USGS) studies of sea-level rise and coastal change will focus both on the U.S. Fish \& Wildlife (FWS) sites (shown) and additional near-shore areas. The initial focus will be on the Blackwater National Wildlife Refuge (NWR). (SET-MH, Surface Elevation Table-Marker Horizon; SHARP, a quasi-three-dimensional, numerical finite-difference model to simulate freshwater and saltwater flow separated by a sharp interface in layered coastal aquifer systems).

restoration activities for degraded ecosystems. Improved characterization and projections of land-use and land-cover information is needed to support conservation and restoration decisions.

Improved land-use information is needed to address the land conservation and healthy watersheds in the Chesapeake Agreement, and support several others including water quality and habitats. Understanding and assessing the vulnerability of lands and healthy watersheds to development is necessary to guide and prioritize conservation efforts throughout the Chesapeake Bay watershed. Forecasts of land-use change and potential effects on nutrient and sediment loads are also needed for the Bay TMDL framework for reducing nutrient and sediment in the Bay. Finally, the combined effects of climate and land-use change are needed to support management strategies for habitat outcomes and contribution to climate adaptation strategies.

The DOI and Federal government have critical land holdings within the Chesapeake Bay watershed, owning approximately 3.2 million acres, which represents about 8 percent of the total watershed land area. DOI FWS National Wildlife Refuges, National Parks, National Forest Lands, and Defense installations are threatened by land development, and in some cases, the additional effects of climate change. Activities in the Chesapeake support the DOI priorities of secure and healthy 
watersheds and landscape decisions and help to protect these vital Federal assets.

To fill these science needs the following cross-cutting questions will be addressed:

- How do land and climate change affect freshwater fish communities and habitats?

- What are the relationships among land use, water quality, contaminants, and the health of fish and wildlife?

- How is the water quality of rivers and estuaries responding to restoration actions, and changing land use?

- Critical supporting questions include:

- Which healthy watersheds are most vulnerable to degradation based on their landscape characteristics and forecasted changes in land use?

- What are some of the vital lands and habitats that are most vulnerable to development?

- What are the historical trends in agriculture and urban land use/cover, 1950-present?

- How much development is occurring and may occur as infill/redevelopment?

- How might future urban development affect nutrient and sediment loads to the Bay?

- What is the relative probability of forest and (or) farmland conversion to urban development throughout the Bay watershed?

\section{Anticipated USGS Activities}

This objective builds on existing activities to provide new land-use change data, and modeling tools to address needs for conservation of lands and watersheds and restoration of water-quality and habitat conditions in an era of projected increases in population. Results of this objective will be used to understand past, present, and future land-use changes, and working with other USGS researchers and partners on how those changes affect water quality, wildlife, habitats, and vital lands and watersheds. Some of the major activities include the following:

- Assess the rates and patterns of impervious surface and riparian forest change in the Bay watershed at a temporal and spatial scale, and level of precision relevant to county-level planning decisions. These results are directly supportive of the land-use methods and metrics development outcome. The results will also be used to help assess the vulnerability of healthy watersheds. The enhanced impervious surface data are also needed to improve modeling of land cover in the watershed (both for the CBP watershed model and the USGS Chesapeake Bay Land-Change Model).

- Enhance local-scale land-use information. Develop a database that integrates the best available land use/ cover related information from local governments and planning agencies with regional data derived from remote sensing products. These data will improve the currently available satellite-based data from 19842011 to help ensure that the next generation of watershed models better reflect local conditions.

- Use land-use change data to support enhancements of the CBP watershed model and the assessment of waterquality trends. Specific activities include the following:

$\checkmark$ Enhance and integrate land-cover data into the CBP model frameworks by developing new land-use classification schemes that are more closely aligned with management strategies.

$\diamond$ Summarize information on historical trends in land use and land cover back to 1950 to better explain observed changes in water quality.

$\diamond$ Inform the Chesapeake Bay Program's 2017 Midpoint Assessment, Phase III WIPs, and State trading and offset strategies with the most current and accurate land use/cover data.

- Refine the Chesapeake land-change model and forecast alternative urbanization scenarios. These results will inform the State WIPs, and nutrient offset and trading strategies. The USGS will work with the CBP Land Use Workgroup to develop alternative urbanization scenarios using the Chesapeake Bay Land Change Model. This effort will then be extended to all jurisdictions in the Mid-Atlantic states.

- Use the Chesapeake Bay Land Change Model to assess vulnerability of healthy watersheds, lands, and critical habitats, specifically for the following:

$\checkmark$ Assess the vulnerability of healthy watersheds to major changes in land use, such as the conversion of forests and farmlands to development or energy extraction activities.

$\diamond$ Use time series remote sensing imagery and U.S. Census data to track urban development in all healthy subbasins in the Chesapeake Bay watershed.

- Present results of these activities in a spatial database of past and present land conservation actions, and provide as products for incorporation into LandScope Chesapeake, a tool for land protection.

- Integrate land vulnerability into climate change activities addressing (1) sea-level rise on coastal wetlands, 
and (2) stream conditions supporting freshwater fisheries to understand the combined effects of land and climate change.

Initial pilot studies for land-use characterization will be developed for all of Maryland and Delaware. Following the pilot studies, the activities will be expanded to include the entire Chesapeake Bay watershed. Land change models will be applied basinwide. Vulnerability assessments will be carried out for all healthy watersheds (fig. 11), wetlands, and for Black Duck and Brook Trout habitats in the Chesapeake Bay watershed.

\section{Science Partners}

The USGS will coordinate with the CBP Land Use Workgroup and Healthy Watershed Goal Implementation
Team, and work with members of the Water-Quality Goal Team to develop methods to improve and collect land data for the entire watershed. Collection and management of these data along with data from local partners have informed the Chesapeake Bay Partnership's restoration activities for water-quality improvement and land management for decades. Additional partners include the UMD's National Center for Smart Growth Research and Education, the Maryland Department of Planning, the EPA's Office of Research and Development, Shippensburg University, the William Penn Foundation, the Geospatial Data Analysis Corporation, The Nature Conservancy, NatureServe, and the the Chesapeake Bay Commission. Water-quality science partners for this objective include a variety of Chesapeake Bay Program workgroups under the Water-Quality Goal Implementation Team.

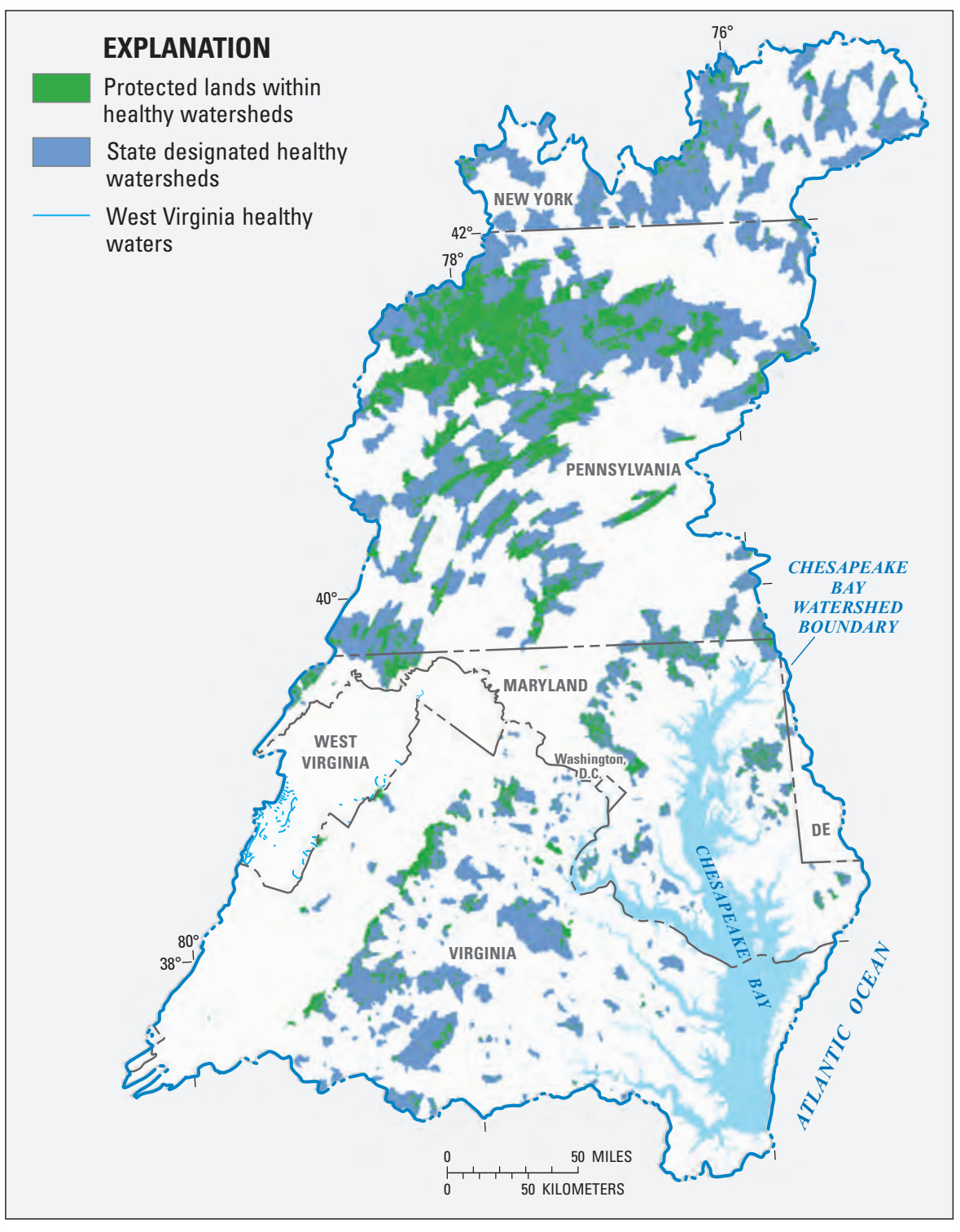

Figure 11. Location of protected lands and healthy watersheds in the Chesapeake Bay ecosystem. U.S. Geological Survey (USGS) forecasts of land change will be used to help identify vulnerable areas of healthy watersheds and protected lands, wetlands, and Black Duck and Brook Trout habitats in the Chesapeake Bay watershed. 


\section{Science Theme 4: Synthesize and Provide Information to Support Ecosystem Management}

Ecosystem restoration and conservation requires scientific findings to be summarized and scientists to interact with decision makers so they best apply the knowledge while understanding the uncertainties of the information. The Chesapeake EO Strategy (U.S. Environmental Protection Agency, 2010) has a goal to "Strengthen science to promote ecosystem-based, adaptive management through enhanced coordination of science and decision-support activities." The Chesapeake Agreement builds upon this goal to emphasize several principles to improve decision making: (1) use science-based decision making, and seek out innovative technologies and approaches; (2) adaptively manage at all levels of the partnership to foster continuous improvement; and (3) explore using social science to better understand and measure how human behavior can drive natural resource use, management, and decision making. This theme will also contribute to the DOI goals to (1) build a landscape-level understanding of our resources; and (2) conserve lands, and ensure safe and secure water supplies.

This science theme focuses on providing scientific information to enhance ecosystem decision making and has three objectives:

- 4.1 Summarize and apply science to inform decision making.

- 4.2 Manage and provide information.

- 4.3 Lead collaborative science activities.

The activities for this objective carry out the USGS Ecosystem MA strategic science goal to apply science to enhance strategies for management, conservation, and restoration of ecosystems. These activities also support the Core Science Systems goals to expand applications of USGS research through scientific services, conduct analysis and synthesis to improve coverage, quality, usability and timeliness of information.

\section{Objective 4.1 Summarize and Apply Science to Inform Decision Making}

\section{Science Needs and Questions}

The CBP has adopted a decision framework to employ adaptive management to improve decision making (fig. 12). Implementation of the Chesapeake Agreement requires that the CBP partners apply adaptive management to inform decision makers. In order to achieve identified outcomes, science is needed to formulate management strategies, conduct monitoring, evaluate progress toward outcomes, and reduce uncertainty for decision making. The CBP decision framework has these components: (1) articulating program goals, (2) describing factors influencing goal attainment, (3) assessing current management efforts and gaps, (4) developing a management strategy, (5) developing a monitoring program, (6) assessing performance, and (7) adapting these components to improve program performance, based on new insights brought forward by this process.

The USGS will emphasize the following science activities to support aspects of the CBP adaptive management approach:

- Further understand the factors that affect achieving outcomes.

- Monitor ecosystem condition and changes.

- Assess and explain the effectiveness of practices and policies to improve ecosystem conditions.

- Interact with decision makers to consider adjustments to management strategies as uncertainty is reduced.

The decision framework will be a primary tool to use science to develop and implement the management strategies for each of the outcomes in the Chesapeake Agreement. The management strategies will be evaluated every 2 years, so there are opportunities to continuously inform decision makers through new scientific insights. Science will be particularly valuable in these elements of the decision framework:

- Factors influencing ability to meet goal-Identify the key natural and human systems that could affect the ability to attain the desired outcome.

- Develop monitoring program-Monitoring is necessary to answer two basic accountability questions: (1) Are we doing what we said we would do?, and (2) Is the outcome what is expected and desired?

- Assess performance - For both accountability and adaptive management it is essential to evaluate the performance of the management effort. Two assessments are needed. For accountability, the question is whether the management intervention was effectively delivered. For adaptive management, it is important to know if the system responded as expected. Did the outcomes appear at the level and at the pace expected?

- Manage adaptively - In order to constantly improve the effectiveness of the management program, there must be a process for continually reducing the uncertainty in management strategies. The decision framework attempts to enable this by promoting explicit 


\section{ADAPTIVE MANAGEMENT FOR THE CHESAPEAKE BAY PROGRAM}

(CBP, 2011)

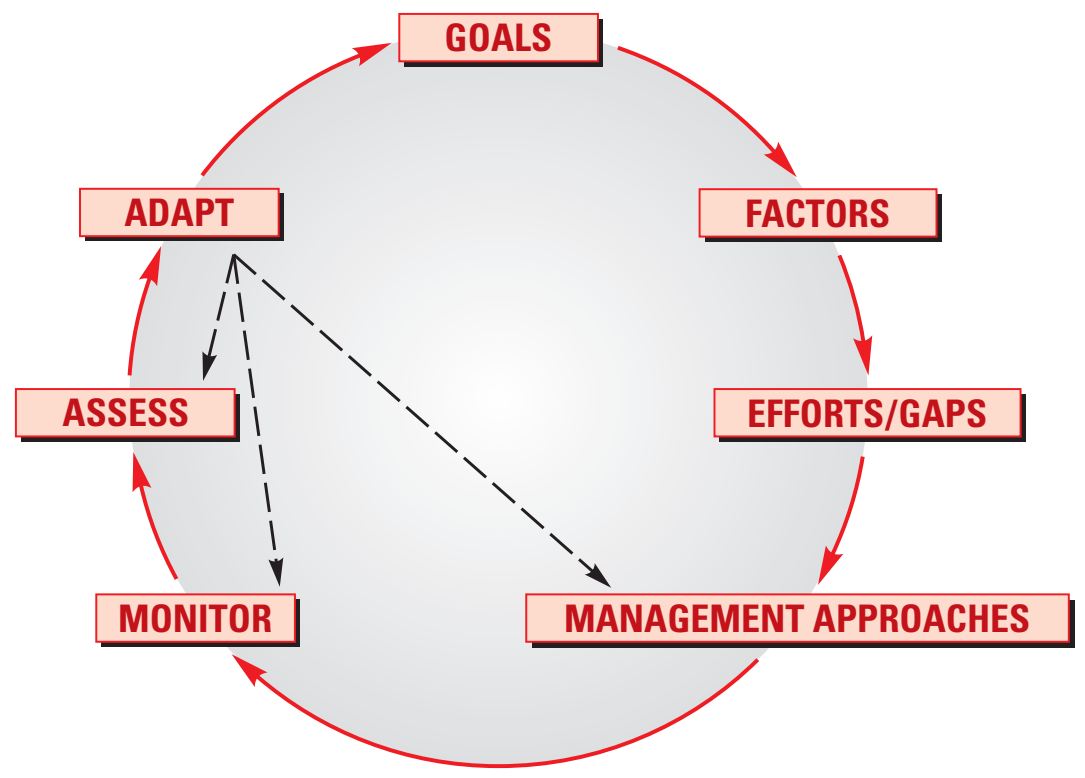

Figure 12. Adaptive management framework for the Chesapeake Bay Program (CBP).

identification of the understanding that drives management efforts and detailed prediction of expected system behavior based on that understanding. Well-designed monitoring then enables constant assessment of the accuracy of that understanding and informs revision of the understanding to increase the certainty of the actions in the next iteration.

This objective will also address these cross-cutting science questions:

- What are some of the best opportunities for aligning science to benefit multiple restoration outcomes?

And these supporting questions:

- How can we better summarize and communicate information, using the CBP adaptive management framework, to enhance the ecosystem decision-making process?

- How can we best create multiple products from complex scientific findings to inform decision makers?

\section{Anticipated USGS Activities}

The two primary activities are (1) summarizing information, and (2) interacting with decision makers using the CBP adaptive management framework. Within the CBP there are many groups of decision makers that are implementing actions and policies in the new Chesapeake Agreement. The USGS has identified key decision makers that need our information (fig. 13):

- CBP Goal Implementation Teams (GITs), which include Federal, State, and local resource managers working on teams to address the CBP goals and outcomes. The GITs have work groups to address many of the outcomes in the Chesapeake Agreement.

- Federal/State Managers, which include (1) upperlevel Federal and State managers, such as the CBP Management Board and Principal Staff Committee; (2) the Chesapeake Federal leadership Committee (FLC); and (3) upper-level managers in the USGS and DOI.

- Local governments and non-governmental organizations (NGOs), which carry out the implementation of restoration and conservation practices and policies in the Bay watershed. Important mechanisms to reach local governments and NGOs are through the Local Government Advisory Committee and the Citizens Advisory Committee, respectively.

- Elected officials, which include the Governors of the Bay states and Congress, who need information on how well practices and policies are being carried out to achieve outcomes. 


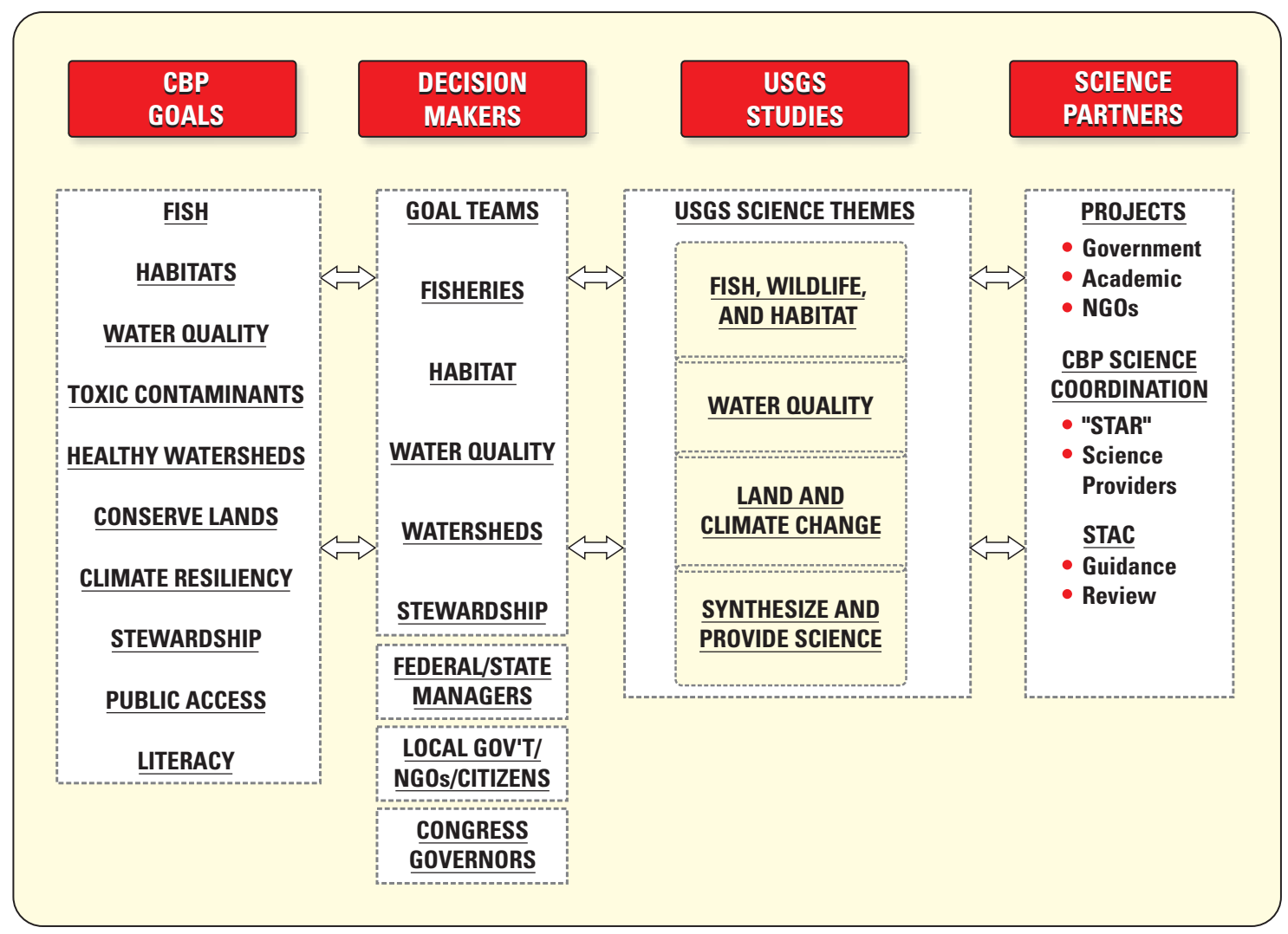

Figure 13. Relation between Chesapeake Bay Program (CBP) goals, decision makers, and U.S. Geological Survey (USGS) activities. The goals in the Chesapeake Agreement (left column) and CBP Goal Teams, and decision makers (second column) will be informed by information from the USGS Chesapeake Bay science themes (third column) working with science partners (fourth column). (NGOs, nongovernmental organizations; STAR, Scientific, Technical Assessment, and Report; STAC, Scientific and Technical Advisory Committee).

To reach these audiences, two major activities will be conducted:

- Summarize findings to inform decision making: The USGS, working with science partners, will synthesize information and interact with decision makers on potential management implications for reaching CBP goals and outcomes. The USGS envisions different types of synthesis products that will be needed for each of the key audiences. "Summary" products, such as fact sheets, press releases, and Web-based stories, that summarize findings from USGS reports or journal articles will be useful to resource managers making ecosystem decisions. Within the CBP, the GITs would be the primary audiences for this information as well as Federal and State managers, and elected officials (local, State, and Federal).

- Interact with decision makers: Within CBP, the USGS will have membership on selected CBP Goal teams and workgroups to enhance direct interaction with decision makers. The USGS will use results from summary products to communicate findings and discuss potential implications with the Goal Teams as they develop and carry out their management strategies. The USGS will work to put Chesapeake results into a national context through synthesis reports with other ecosystems and at national meetings and conferences. The USGS Office of Communications and Publishing is a primary partner to help communicate results both internally and to key audiences.

\section{Science Partners}

The CBP Communications Office will be a close partner to provide results to $\mathrm{CBP}$ audiences and the interested general public. The UMCES will be the primary academic partner to help prepare selected synthesis products. Partnerships with all the Goal Teams will be carried out to release information on topics that relate to each team. 


\section{Objective 4.2 Manage and Provide Information}

\section{Science Needs and Questions}

The USGS Core Science System Strategy Report (2012) states "challenging scientific questions require the analysis and integration of information and data across scientific disciplines." To meet the Chesapeake Agreement needs and support the core questions and activities of the other USGS themes, information resources need to be provided and managed efficiently. The CBP commitment is to share and increase access to scientific results and information. Data from monitoring and science activities are needed to support and carry out management strategies being developed for the Chesapeake Agreement. Providing information is the foundation of the DOI priority for landscape understanding.

The science questions to address these needs include the cross-cutting and supporting questions "What are some of the best opportunities to align science to benefit multiple restoration outcomes?"

- How can we improve internal, external, and machineto-machine access to USGS information?

- How can we use data management best practices to improve project workflows and protect information resources?

- How can we better integrate information from USGS science themes to facilitate cross-cutting analyses?

\section{Anticipated USGS Activities}

This objective enhances data management for the other themes of the USGS Chesapeake Science Strategy and approaches to provide data to key audiences.

- Fish, Wildlife, and Habitats Theme-The USGS will increase emphasis on managing and providing fish health, wildlife, habitat, and water-quality contaminant information by improving Web accessible data delivery applications and Data Management activities recommended by the USGS Core Science Analytics, Synthesis, and Libraries MA. The major outcome of this focus will be Data Management Plans (DMPs) that will facilitate building technical solutions to better manage this information as well as build integrated databases to provide increased access and analytical capability.

- Water-Quality Theme-The USGS will continue Web site activities for providing Nontidal Network waterquality trends and results. The Nontidal Network Website will be updated and improved annually to provide new trends and results information to partners.
Water-quality information is currently collected and managed at an agency wide level. This information will not require an additional DMP or database development.

- Climate and Land Change Theme-Products including a protected lands data layer and statistical derivatives will be provided to the Chesapeake LandScope Web site working group, which includes NatureServe and the NPS. The USGS may also support future development of a protected lands statistical Web analysis tool to be provided on the Chesapeake LandScope Web site. Data management components including DMPs will be applied to the collection of land management data from State or County partners to improve integration and facilitate analysis. Emphasis will be on providing a series of maps accessible in a variety of Web formats that will inform partners on wetland loss for several sea-level rise projections.

- Providing Information Theme-The USGS will continue to develop Web applications for sharing data to support increased access to scientific results and information. At least one product will be a custom portal on the USGS Chesapeake Bay Studies Web site that will be built upon the USGS's ScienceBase data catalog service. Data for public release will also be indexed on USGS's Science Data Catalog as part of agency requirements. In addition, the USGS will increase awareness of project activities by developing a publically accessible Web map viewer showing USGS project locations and selected monitoring networks.

\section{Science Partners}

The USGS will improve technical solutions to integrate and share data with the CBP partners. The USGS will work with the CBP Data Enterprise to improve discovery and access of data through the Chesapeake Bay Data Hub, metadata catalog, and ScienceBase and (or) Data.gov. Additionally, through the CBP STAR Team, and the Data Integrity Workgroup, the USGS will work with the Chesapeake Bay Data Enterprise to help identify and support priority data flows to benefit the GITs.

\section{Objective 4.3 Lead Collaborative Science Activities}

Both internal and external collaboration is needed to conduct and fund USGS Chesapeake Bay science activities. Science collaboration includes (1) collaboration among USGS scientists to conduct monitoring and research efforts, (2) working with science partners, and (3) aligning resources to support the science efforts. 


\section{Science Needs and Questions}

The Chesapeake Agreement has a principle to "maintain a coordinated watershed-wide monitoring and research program to support decision making and track progress and the effectiveness of management actions." Collaboration between USGS scientists and partners is needed to address crosscutting questions and carry out science activities to improve decision making for the Chesapeake Agreement. The USGS provides critical science for the DOI to have a leadership role in the new Chesapeake Agreement with priorities related to restore and protect fish, wildlife, and people. Coordination between USGS MAs, Programs, and the DOI is critical to fund projects, and demonstrate to Congress, the Administration, and the public that funds are used effectively.

The science questions to meet the needs include:

- What are some of the best opportunities to align science to benefit multiple restoration outcomes?

- How can we use or modify the CBP structure to coordinate activities to provide effective partnerships between science providers?

- How can we enhance collaboration among USGS scientists and management to enhance collaboration to address cross-cutting activities to address complex scientific issues?

\section{Anticipated USGS Activities}

The major activities are focused on enhancing USGS science partnerships, increasing collaboration among USGS scientists, and improving interactions with USGS MAs and Programs. The USGS directly collaborates with the science partners on a majority of our studies (fig. 13). The USGS will work through CBP STAR team to discuss activities with Federal, State, and academic institutions to coordinate efforts of science providers to meet the expanded science needs of the Chesapeake Agreement. The major functions of STAR include the following:

- Manage CBP-funded monitoring networks and coordinate with additional science providers to utilize additional networks to address the new Chesapeake Agreement.

- Ensure information quality, management, and access.

- Update, and deliver, the status and trends (indicators) of ecosystem conditions.

- Explain ecosystem conditions and change.

- Expand modeling to better understand and predict ecosystem response.
- Coordinate climate change activities.

- Synthesize and communicate results to improve decision making among the partners.

The STAC also provides a format for collaboration on science activities. The STAC includes academic and Federal science providers and advises the $\mathrm{CBP}$ on science needs and activities. The STAR has a collaborative relationship with the STAC. The STAC provides independent review and recommendations to the CBP to enhance science (monitoring, modeling, and research). The STAR works with science providers and Goal Teams to implement the STAC recommendations.

Collaboration among scientists has been a hallmark of addressing complex questions since the inception of USGS Chesapeake Bay studies. Many scientists effectively work together on projects, and the USGS Chesapeake Science Team is the primary mechanism to enhance collaboration among USGS scientists to address complex issues. Responsibilities of the Chesapeake Science Team include the following:

- Set directions and priorities for USGS Chesapeake Science Themes and Objectives.

- Organize meetings of USGS investigators to promote collaboration toward addressing cross-cutting science questions. These include joint products and activities.

- Interact with science partners to coordinate activities.

- Identify opportunities and lead interaction with decision makers to apply science findings to management issues.

- Interact with USGS Management (MAs and Science Centers) to align investigators and funding.

\section{Science Partners}

USGS will work with a broad array of Federal, State, academic, and local science partners, most of which are listed in figure 13 .

\section{Acknowledgments}

The USGS Chesapeake Bay Science Team wishes to acknowledge staff, managers, and partners who help restore the Nation's largest estuary. Efforts of USGS staff who collect data are critical to understand ecosystem conditions and response. The research to analyze and understand the data provides the scientific underpinning for decision makers. The resources provided by USGS MAs, Programs, and DOI allow the efforts to be carried out within USGS Science Centers and with partners across the watershed. 


\section{References Cited}

Chesapeake Bay Foundation, 2014, The economic benefits of cleaning up the Chesapeake: Annapolis, Maryland, Chesapeake Bay Foundation, 56 p., accessed September 5, 2015, at http://www.cbf.org/document.doc?id=2258.

Chesapeake Bay Program, 2013, Bay barometer, 2011-2012, Spotlight on health and restoration in the Chesapeake Bay and its watershed, 10 p., accessed September 5, 2015, at http://www.chesapeakebay.net/documents/10-Pg_CBP_ Barometer_for_web.pdf.

Claggett, P.R., 2007 Human population growth and land-use change in Phillips, S.W., ed., Synthesis of U.S. Geological Survey science for the Chesapeake Bay ecosystem and implications for environmental management: U.S. Geological Survey Circular 1316, 63 p., accessed August 1, 2015, at http://pubs.usgs.gov/circ/circ1316/.

Council on Climate Preparedness and Resilience, 2014, Priority agenda for enhancing the climate resilience of America's natural resources, 79 p., accessed September 5, 2015, at https://www.whitehouse.gov/sites/default/files/ docs/enhancing_climate_resilience_of_americas_natural_resources.pdf.

Gottschalk, K. Abdalla, C., Benham, B., Chambers, R., Gardner, N., Howarth, R., Maloney, K. and Wardrop, D., 2013, Exploring the environmental effects of shale gas development in the Chesapeake Bay watershed: Chesapeake Bay Program Scientific and Technical Advisory Committee report (CRC\# STAC 13-01), 30 p., accessed September 5, 2015, at http://www.chesapeake.org/ pubs/297_Gottschalk2013.pdf.

Phillips, S.W., 2011, USGS science for the Chesapeake Bay restoration: U.S. Geological Survey Fact Sheet 2010-3081, 2 p., accessed August 1, 2015, at http://pubs.usgs.gov/ fs $/ 2010 / 3081 /$.

Rice, K.C., and Jastram, J.D., 2014, Rising air and stream-water temperatures in Chesapeake Bay region, USA: Journal of Climate Change, v. 128, nos. 1-2, p. 127-138, DOI 10.1007/s10584-014-1295-9, accessed August 1, 2015, at http://link.springer.com/ article/10.1007\%2Fs10584-014-1295-9\#page-1.

U.S. Department of the Interior, 2014, Strategic plan for fiscal years 2014-2018: Washington, D.C., U.S. Department of the Interior, 56 p., accessed August 1, 2015, at https:// www.doi.gov/sites/doi.gov/files/migrated/bpp/upload/DOIStrategic-Plan-for-FY-2014-2018-POSTED-ON-WEBSITE. pdf.
U.S. Environmental Protection Agency, 2008, Bay barometer-A health and restoration assessment of the Chesapeake Bay and watershed in 2008: U.S. Environmental Protection Agency, EPA-90-R-09-001, 40 p., accessed September 5, 2015, at http://www.chesapeakebay.net/content/publications/cbp_34915.pdf.

U.S. Environmental Protection Agency, 2010, Strategy for protecting and restoring the Chesapeake Bay watershed: Executive Order 13508, Developed by the Chesapeake Federal Leadership Committee, EPA-903-R-10-003, 173 p., accessed September 5, 2015, at http://executiveorder.chesapeakebay.net/file.axd?file $=2010 \% 2 \mathrm{f} 5 \% 2 \mathrm{fCh}$ esapea ke+EO+Strategy\%20.pdf.

U.S. Environmental Protection Agency, U.S. Geological Survey, and U.S. Fish and Wildlife Service, 2012, Toxic contaminants in the Chesapeake Bay and its watershed: Extent and severity of occurrence and potential biological effects: Annapolis, Maryland, U.S. Environmental Protection Agency Chesapeake Bay Program Office, 175 p., accessed September 5, 2015, at http://executiveorder.chesapeakebay.net/ChesBayToxics_finaldraft_11513b.pdf.

\section{Appendix. Chesapeake Agreement}

The Chesapeake Agreement is available at: http://www. chesapeakebay.net/documents/FINAL_Ches_Bay_Watershed_ Agreement.withsignatures-HIres.pdf. 

Prepared by USGS Rolla and West Trenton Publishing Service Centers.

Edited by Rebekah J. Davis.

Proofed by Valerie M. Gaine.

Graphics and layout by Timothy W. Auer.

For additional information, visit the

USGS Chesapeake Bay Activities

Web site at:

http://chesapeake.usgs.gov 


\section{אב \\ कू}

